
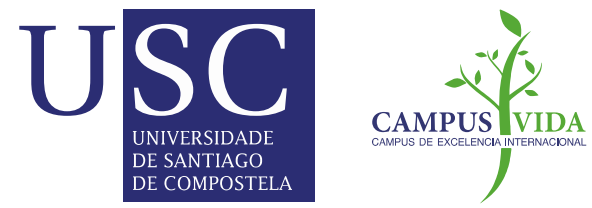

\title{
Assessment of a fast method to predict the biochemical methane potential based on biodegradable COD obtained by fractionation respirometric tests
}

Argiz L., Reyes C., Belmonte M., Franchi O., Campo R., Fra-Vázquez A., Val del Río A., MosqueraCorral A., Campos J.L.

\section{Accepted Manuscript}

\section{How to cite:}

Journal of Environmental Management. Volume 269, 1 September 2020, 110695.

Doi: 10.1016/j.jenvman.2020.110695

\section{Copyright information:}

(C) 2020 Elsevier Ltd. This manuscript version is made available under the CC-BY-NC-ND 4.0 license (http://creativecommons.org/licenses/by-nc-nd/4.0) 


\section{Assessment of a fast method to predict the biochemical methane potential based on biodegradable COD obtained by fractionation}

Argiz L. ${ }^{\text {* }}$, Reyes C. ${ }^{\mathrm{b}}$, Belmonte M. ${ }^{\mathrm{b}}$, Franchi O. ${ }^{\mathrm{c}}$, Campo R. ${ }^{\mathrm{d}}$, Fra-Vázquez A. ${ }^{\mathrm{a}}$, Val del Río A. ${ }^{a}$, Mosquera-Corral A. ${ }^{a}$, Campos J.L. ${ }^{\mathrm{c}}$

${ }^{a}$ CRETUS-Institute, Universidade de Santiago de Compostela, 15782 Santiago de Compostela, Galicia, Spain

${ }^{\text {b }}$ Laboratorio de Biotecnología, Medio Ambiente e Ingeniería (LABMAI), Facultad de Ingeniería, Universidad de Playa Ancha, Avda. Leopoldo Carvallo 270, 2340000 Valparaíso, Chile.

${ }^{\mathrm{c}}$ Facultad de Ingeniería y Ciencias, Universidad Adolfo Ibáñez, Avda. Padre Hurtado 750, Viña del Mar, Chile.

d Dipartimento di Ingegneria Civile e Ambientale (DICEA), Università degli Studi Firenze, Via di Santa Marta, 3, 50139 Firenze, Italy.

* Corresponding author. Tel.: +34 881816784. E-mail address: luciaargiz.montes@ usc.es 


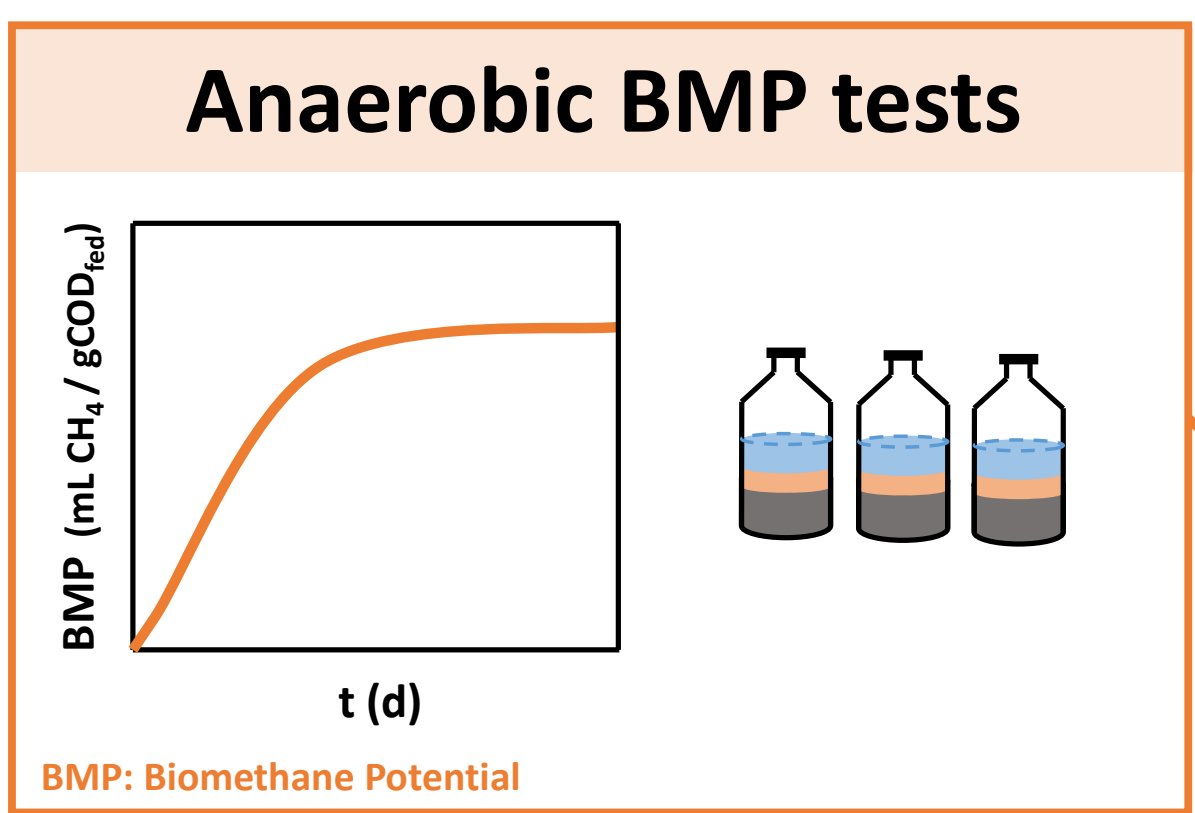

\section{Aerobic COD fractionation}

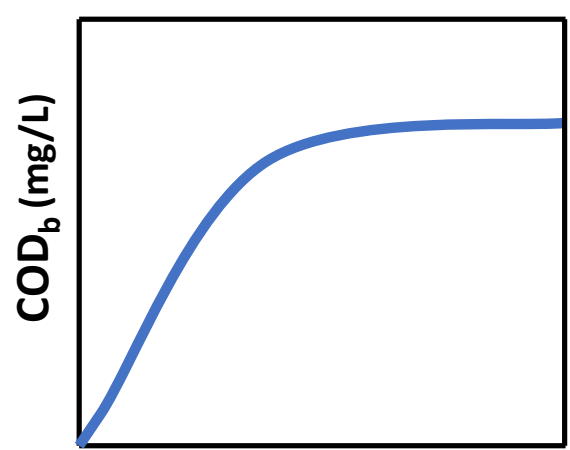

$\mathbf{t}(\mathrm{h})$

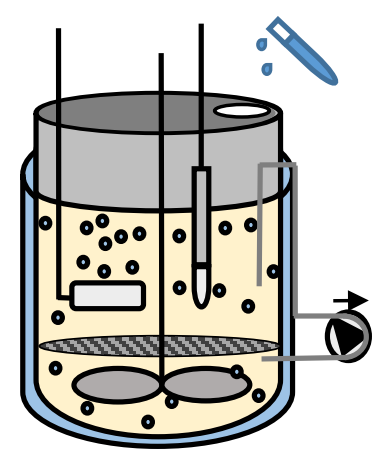

gen Demand

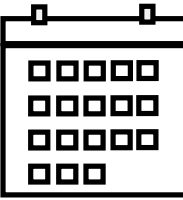

Time - consuming

(weeks - months)

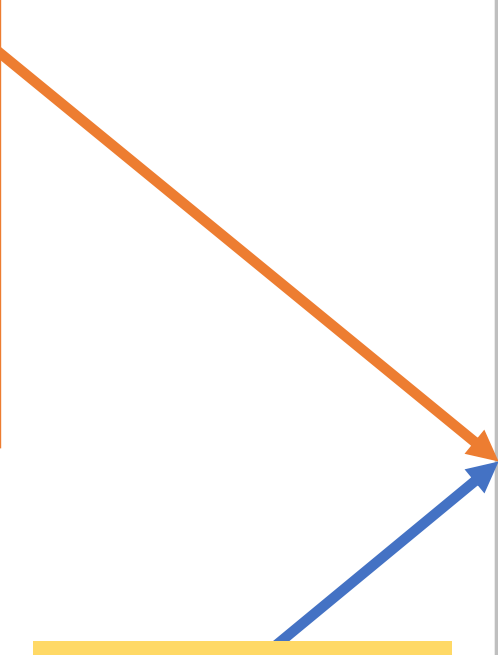

Faster alternative?

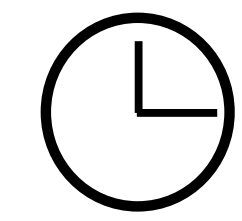

Early prediction (hours)

\section{Different substrates tested, 2 laboratories}

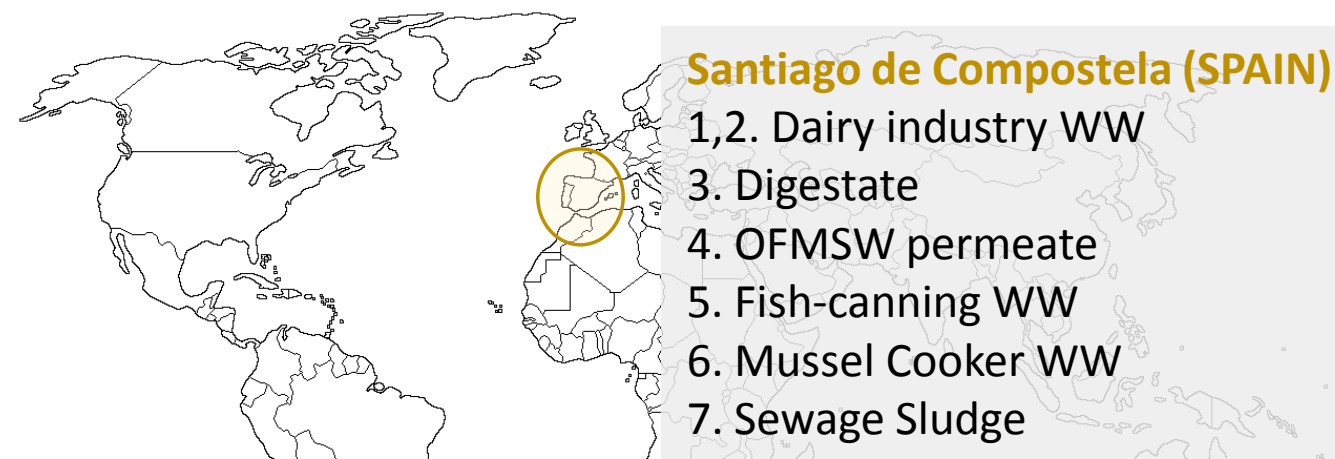

Viña del Mar (CHILE)

8. Wine industry WW

9. Tobacco industry WW

10. Chipboard factory WW

11. Slaughterhouse WW

WW: wastewate

Methanized $\operatorname{COD}\left(\operatorname{COD}_{\text {met }}\right)=$ Biodegradable $\operatorname{COD}\left(\operatorname{COD}_{b}\right)$

$$
\mathrm{BMP}=\frac{\mathrm{COD}_{\mathrm{b}} \cdot 350 \mathrm{~mL} \mathrm{CH} / \mathrm{g} C O D}{\mathrm{COD}_{\mathrm{fed}}}
$$




\section{Highlights}

- A novel and rapid methodology for BMP prediction based on COD fractionation.

- Eleven substrates of diverse nature, origin and complexity were tested.

- Methanized COD coincided with biodegradable soluble + particulate fractions.

- Testing time was reduced from weeks-months (BMP) to hours-days (COD fractionation).

- An interlaboratory comparison validated the developed methodology. 


\section{Assessment of a fast method to predict the biochemical methane}

\section{2 potential based on biodegradable COD obtained by fractionation}

3 Argiz L. ${ }^{\mathrm{a}}$, , Reyes C. ${ }^{\mathrm{b}}$, Belmonte M. ${ }^{\mathrm{b}}$, Franchi O. ${ }^{\mathrm{c}}$, Campo R. ${ }^{\mathrm{d}}$, Fra-Vázquez A. ${ }^{\mathrm{a}}$, Val del Río

$4 \quad$ A. $^{\text {a }}$, Mosquera-Corral A. ${ }^{a}$, Campos J.L. ${ }^{\mathrm{c}}$

5 a CRETUS-Institute, Universidade de Santiago de Compostela, 15782 Santiago de Compostela, Galicia, 6 Spain

7 b Laboratorio de Biotecnología, Medio Ambiente e Ingeniería (LABMAI), Facultad de Ingeniería, 8 Universidad de Playa Ancha, Avda. Leopoldo Carvallo 270, 2340000 Valparaíso, Chile.

$9 \quad{ }^{\mathrm{c}}$ Facultad de Ingeniería y Ciencias, Universidad Adolfo Ibáñez, Avda. Padre Hurtado 750, Viña del Mar, 10 Chile.

11 dipartimento di Ingegneria Civile e Ambientale (DICEA), Università degli Studi Firenze, Via di Santa 12 Marta, 3, 50139 Firenze, Italy.

13 * Corresponding author. Tel.: +34 881816784. E-mail address: luciaargiz.montes@usc.es

ABSTRACT

16

The biochemical methane potential test (BMP) is the most common analytical technique to predict the performance of anaerobic digesters. However, this assay is time-consuming (from 20 to over than 100 days) and consequently impractical when it is necessary to obtain a quick result. Several methods are available for faster BMP prediction but, unfortunately, there is still a lack of a clear alternative. Current aerobic tests underestimate the BMP of substrates since they only detect the easily biodegradable COD. In this context, the potential of COD fractionation assays, which allow the determination of the particulate slowly biodegradable fraction, was evaluated here as an alternative to early predict the BMP of substrates. Seven different origin waste streams were tested and the anaerobically biodegraded organic matter $\left(\mathrm{COD}_{\mathrm{met}}\right)$ was compared with the different COD fractions. When considering adapted microorganisms, the appropriate operational conditions and the required biodegradation time, the differences between the $\mathrm{COD}_{\text {met }}$, determined through BMP tests, and the biodegradable $\mathrm{COD}\left(\mathrm{COD}_{\mathrm{b}}\right)$ obtained by respirometry, were not significant $\left(\mathrm{COD}_{\text {met }}(57.8026 \pm 21.2875)\right.$ and $\mathrm{COD}_{\mathrm{b}}(55.6491 \pm 21.3417), \mathrm{t}(5)=0.189, \mathrm{p}=$ 0.853). Therefore, results suggest that the BMP of a substrate might be early predicted from its $\mathrm{COD}_{\mathrm{b}}$ in only few hours. This methodology was validated by the performance of an inter-laboratory study carried out in Chile considering four additional substrates.

Keywords: anaerobic digestion; biodegradability; BMP; COD fractionation. 


\section{INTRODUCTION}

The European Union (EU) is working towards a climate-neutral Europe by 2050. Key targets for 2030 include reducing greenhouse gas emissions (at least $40 \%$ from 1990 levels), increasing the share of renewable energy usage (at least $32 \%$ ) and improving energy efficiency (at least $32.5 \%$ ). In this context, the anaerobic digestion process (AD) will contribute to achieving these objectives (Mottet et al., 2009). Biodegradable organic materials can be profitably used as renewable energy sources (RES) since they can be converted into methane-rich biogas $(60-70 \%)$ (Da Silva et al., 2018). Over the past two decades, the growing paradigm-shift from fossil fuels to RES, including biogas was focused on three industrial sectors: transport, heating/cooling and power/electricity production (Malico et al., 2019; Sherwood, 2020). Banja et al. (2019) reported that the largest share of financial measures implemented over the period 2005 - 2015 was dedicated to favour biomass processing for electricity production and $36 \%$ was meant for heating/cooling purposes. In the heating/cooling sector, a $35.7 \%$ of the total measures were dedicated to biogas whereas in the transport sector, these constituted less than $5 \%$.

Many feedstocks are suitable for biogas production if they contain carbohydrates, proteins, fats, cellulose and hemicelluloses as the main components. Nonetheless, the biomethane production depends on several factors: nutrients, total and volatile solids (TS and VS), chemical oxygen demand concentrations (COD), and carbon/nitrogen ratio $(\mathrm{C} / \mathrm{N})$. In addition, the presence of substances like free ammonia (FA), $\mathrm{H}_{2} \mathrm{~S}$, light metal ions (e.g. sodium, potassium and magnesium), heavy metal ions (e.g. chromium, iron and cobalt) and certain organic compounds (e.g. alkyl benzenes, halogenated benzenes and alcohols) can inhibit the process leading to low methane production yields and process instability (Chen et al., 2008; Jingura and Kamusoko, 2017). 
The evaluation of the ultimate amount of methane produced under anaerobic conditions $\left(\mathrm{mL} \mathrm{CH}_{4} / \mathrm{g} \mathrm{COD}\right)$ and the production kinetics (Lesteur et al., 2010) are crucial in order to predict the performance of the anaerobic digestion process (Kianmehr et al., 2013). The Biochemical Methane Potential (BMP) test is the most common assay in this context (Kianmehr et al., 2013), due to its validity and reliability (Lesteur et al., 2010). Its general principle consists of mixing an organic feedstock with an inoculum under experimental conditions that mimic the AD conditions in real practice (Lesteur et al., 2010), and quantify the gas produced by manometric or volumetric methods (Jingura and Kamusoko, 2017). However, the BMP test is time-consuming (from 20 to over 100 days) (Da Silva et al., 2018). Automatic BMP tests have been recently developed with the aim of reducing the disadvantages of the conventional ones. They directly measure the methane production on-line, require less labour, use inexpensive equipment and provide high quality and adequate quantity of data (Jingura and Kamusoko, 2017). Unfortunately, automatic BMP tests are also based on microbial processes and consequently very time-consuming (Kianmehr et al., 2013).

In order to reduce the time needed for the prediction of the biochemical methane production and the anaerobic digestion kinetics, different experimental and theoretical strategies have been studied (Table 1). However, most of these alternatives were studied with solid substrates and even though they are shorter, they still present important disadvantages in comparison to BMP tests. Theoretical methods presume complete degradation of organic matter and for this reason the obtained BMP is over-estimated; mathematical models are complex and require exhaustive organic matter characterization; spectroscopic methods and destructive techniques are expensive and still require more time for development and validation; and the so-called respirometric tests underestimate the BMP of the substrates (Jingura and Kamusoko, 2017; Lesteur et 


\section{.}

al., 2010). Current respirometric tests present an incubation time (from 5 to 30 days) shorter than BMP tests (up to 100 days) and their set-up is technically simpler. However, they only detect the readily available and easily degradable organic matter (Bayard et al., 2016; Cossu and Raga, 2008).

Previous experiences concerning the comparison between anaerobic and aerobic biodegradation of different substrates in very diverse reaction systems (Table 2) showed that, in general, although kinetics were very different, the potentially biodegraded organic matter was almost the same. In addition, Bayard et al. (2018) observed that the biodegradability of municipal solid waste was controlled by the specific features of the substrates tested rather than the environmental conditions (aerobic or anaerobic). This result suggests that it might be possible to predict the BMP of substrates using aerobic respirometric tests if these were able to detect not only the easily biodegradable fraction but also the particulate slowly biodegradable one, which is possible towards COD fractionation assays.

The objective of the present study was to find a relationship between the anaerobically degraded COD, obtained through conventional BMP tests, and the aerobically biodegraded COD, determined by respirometric COD fractionation assays, with the aim of early predicting the ultimate biochemical methane production of a certain substrate without requiring further BMP tests. 
Table 1. Alternative methods for predicting the anaerobic biodegradability.

\begin{tabular}{|c|c|c|}
\hline Method & Substrate & Reference \\
\hline \multicolumn{3}{|c|}{ Theoretical methods } \\
\hline $\begin{array}{l}\text { Stoichiometric analysis } \\
\text { (Buswell Formula) }\end{array}$ & $\begin{array}{l}\text { Animal slurry \& Energy crops } \\
\text { Vinegar residue } \\
\text { Lignocellulosic biomass }\end{array}$ & $\begin{array}{l}\text { Triolo et al., } 2011 \\
\text { Feng et al., } 2013 \\
\text { Thomsen et al., } 2014\end{array}$ \\
\hline $\begin{array}{l}\text { Energy value of feedstocks } \\
\text { estimated from its elemental } \\
\text { composition (Modified Dulong } \\
\text { formula) }\end{array}$ & Food waste & Browne and Murphy, 2013 \\
\hline Chemical composition & $\begin{array}{c}\text { Maize } \\
\text { Biomass material } \\
\text { Fruit and vegetable solid }\end{array}$ & $\begin{array}{l}\text { Rath et al., } 2013 \\
\text { Godin et al., } 2015 \\
\text { Gunaseelan, } 2004\end{array}$ \\
\hline \multicolumn{3}{|c|}{ Mathematical Models } \\
\hline $\begin{array}{l}\text { Biodegradability prediction by } \\
\text { Artificial Neural Networks }\end{array}$ & Wastewater \& waste activated sludge & Kianmehr et al., 2013 \\
\hline $\begin{array}{c}\text { Regression models between } \\
\text { biogas potential and certain } \\
\text { chemical and biological } \\
\text { parameters }\end{array}$ & Waste activated sludge & Mottet et al., 2009 \\
\hline $\begin{array}{l}\text { Mathematical methodology for } \\
\text { the prediction of maximum } \\
\text { methane production and kinetic } \\
\text { parameters }\end{array}$ & $\begin{array}{l}\text { Sewage sludge, a mixture of sewage } \\
\text { sludge \& slaughterhouse wastes }\end{array}$ & Da Silva et al., 2018 \\
\hline $\begin{array}{l}\text { Mathematical correlations } \\
\text { between variables }\end{array}$ & $\begin{array}{c}\text { A large variety of lignocellulosic } \\
\text { biomass materials and related organic } \\
\text { residues }\end{array}$ & Bayard et al., 2016 \\
\hline $\begin{array}{c}\text { Assessment and validation of } \\
\text { previously developed linear } \\
\text { regression models }\end{array}$ & Grassland biomass & Dandikas et al., 2018 \\
\hline $\begin{array}{l}\text { BMP prediction from test data } \\
\text { recorded in the first two weeks }\end{array}$ & Treated municipal solid waste & Howell and Bennett, 2019 \\
\hline \multicolumn{3}{|c|}{ Spectroscopic techniques } \\
\hline $\begin{array}{l}\text { Mid-infrared (MIR) } \\
\text { spectrometry }\end{array}$ & $\begin{array}{c}\text { Crop residues, grasses \& hedge \& tree } \\
\text { trimmings. }\end{array}$ & Bekiaris et al., 2015 \\
\hline $\begin{array}{l}\text { Near-infrared (NIR) } \\
\text { spectrometry }\end{array}$ & $\begin{array}{l}\text { Municipal solid waste, rice, cardboard, } \\
\text { lignocellulosic material \& food wastes }\end{array}$ & Ward, 2016 \\
\hline $\begin{array}{c}\text { Envital Kit (based on } \\
\text { fluorescence redox indicator) }\end{array}$ & Sewage sludge & Bellaton et al., 2016 \\
\hline $\begin{array}{l}\text { Ultra-violet-visible } \\
\text { spectrometry (UV-vis) }\end{array}$ & Olive Mill Wastewater & El Hajjouji et al., 2008 \\
\hline \multicolumn{3}{|c|}{ Destructive techniques combined with fast analytical techniques } \\
\hline $\begin{array}{l}\text { Pyrolysis combined with GC- } \\
\text { MS and }\end{array}$ & Wastewater sludge & $\begin{array}{c}\text { Jarde et al., } 2003 \\
\text { Parnaudeau and Dignac, } 2007\end{array}$ \\
\hline Advanced oxidation processes & Carbohydrates & Roig and Thomas, 2003 \\
\hline \multicolumn{3}{|c|}{ Physicochemical methods } \\
\hline $\begin{array}{l}\text { Electrical conductivity test, } \\
\text { Soluble Chemical Oxygen } \\
\text { Demand test and enzymatic } \\
\text { hydrolysis test. }\end{array}$ & Ensiled Meadow Grass & Tsapekos et al., 2015 \\
\hline \multicolumn{3}{|c|}{ Aerobic tests } \\
\hline $\begin{array}{l}\text { The link between aerobic and } \\
\text { anaerobic biodegradability of } \\
\text { sludge }\end{array}$ & Activated sludge & Ekama et al., 2007 \\
\hline $\begin{array}{l}\text { Aerobic tests as shorter } \\
\text { respirometric tests }\end{array}$ & Municipal waste from landfills & $\begin{array}{c}\text { Cossu and Raga, } 2008 \\
\text { Wagland and Tyrrel, } 2010 \\
\text { Ponsá et al., 2008 } \\
\end{array}$ \\
\hline $\begin{array}{l}\text { prediction of the methane } \\
\text { generation rate constant using a } \\
\text { large-scale respirometer }\end{array}$ & Municipal waste from landfills & Park et al., 2017 \\
\hline
\end{tabular}




\begin{tabular}{|c|c|c|c|c|c|}
\hline \multirow{2}{*}{ Substrate } & \multicolumn{2}{|c|}{ Anaerobic system } & \multicolumn{2}{|c|}{ Aerobic system } & \multirow{2}{*}{ Reference } \\
\hline & Performance & Results & Perfomance & Results & \\
\hline $\begin{array}{l}\text { Pharmaceutical wastewater from the } \\
\text { industrial production of antibiotics } \\
\text { consisting of an aqueous mixture of cleaning } \\
\text { wastewaters, cleaning products, antibiotics, } \\
\text { solvents, and intermediates. }\end{array}$ & $\begin{array}{l}\text { Zahn-Welles test } \\
\text { methodology }\end{array}$ & $\begin{array}{l}70 \% \text { TOC removal after } 12 \text { days } \\
\text { diluting the substrate and } 63 \% \text { TOC } \\
\text { removal after } 28 \text { days considering } \\
\text { the raw substrate. }\end{array}$ & $\begin{array}{l}\text { Adaptation of the } \\
\text { method proposed by } \\
\text { Owen et al., } 1979\end{array}$ & $\begin{array}{l}80 \% \text { and } 89 \% \text { of TOC removal } \\
\text { after } 28 \text { days with the diluted and } \\
\text { the raw substrate, respectively. }\end{array}$ & Marcelino et al., 2016 \\
\hline $\begin{array}{l}\text { Industrial strength } 2,4- \\
\text { dychlorophenoxyacetic acid }(2,4-\mathrm{D}) \\
\text { wastewater in the presence of glucose. }\end{array}$ & $\begin{array}{l}\text { Lab-scale anaerobic } \\
\text { SBR }\end{array}$ & $\begin{array}{c}\text { Complete biodegradation of } 100 \\
\mathrm{mg} / \mathrm{L} \text { after } 24 \text { days. Total } \\
\text { biodegradation was limited to } 120 \\
\mathrm{mg} / \mathrm{L} \text {. }\end{array}$ & $\begin{array}{l}\text { Lab-scale aerobic } \\
\text { SBR }\end{array}$ & $\begin{array}{c}\text { Complete biodegradation of } 100 \\
\mathrm{mg} / \mathrm{L} \text { after } 12 \text { days. Total } \\
\text { biodegradation was limited to } 600 \\
\mathrm{mg} / \mathrm{L} \text {. }\end{array}$ & $\begin{array}{l}\text { Elefsiniotis and } \\
\text { Wareham, } 2013 \\
\text { Celis et al., } 2008\end{array}$ \\
\hline $\begin{array}{l}\text { Bleaching pulp mill acid and alkaline } \\
\text { effluents. }\end{array}$ & $\begin{array}{l}\text { Adapted Zahn- } \\
\text { Welles test } \\
\text { methodology }\end{array}$ & $\begin{array}{c}\text { Degradation of } 62 \% \text { COD in the } \\
\text { acid effluent and } 58 \% \text { COD the } \\
\text { alkaline in } 30 \text { days. }\end{array}$ & $\begin{array}{l}\text { Method of Field et al., } \\
1989\end{array}$ & $\begin{array}{c}\text { Degradation of } 68 \% \text { COD in the } \\
\text { acid effluent and } 75 \% \text { COD the } \\
\text { alkaline for } 2 \text { days. }\end{array}$ & Amaral et al., 2015 \\
\hline $\begin{array}{l}\text { Slaughterhouse wastewater with high blood } \\
\text { content. }\end{array}$ & UASB reactor & $\begin{array}{c}80 \% \text { COD degradation after } 20 \\
\text { days. }\end{array}$ & $\begin{array}{l}\text { COD fractionation } \\
\text { respirometric tests }\end{array}$ & $\begin{array}{c}84 \% \text { degradation of COD (51\% } \\
\text { rapidly hydrolyzable and } 33 \% \\
\text { slowly hydrolysable). }\end{array}$ & Del Pozo et al., 2003 \\
\hline Wastewater with pesticide content. & Anaerobic SBR & $\begin{array}{l}99 \% \text { pesticide removal and } 93 \% \\
\text { TOC removal after } 200 \text { days. }\end{array}$ & SBBR & $\begin{array}{l}88 \% \text { pesticide removal and } 80 \% \\
\text { TOC removal after } 250 \text { days. }\end{array}$ & Al Momani et al., 2010 \\
\hline $\begin{array}{c}\text { Waste Activated Sludge from an urban } \\
\text { WWTP }\end{array}$ & $\begin{array}{l}\text { Anaerobic digestion } \\
\text { batch lab-scale tests }\end{array}$ & $\begin{array}{c}65 \% \text { of protein degradation and } 66 \\
\% \text { of VS after } 94 \text { days. }\end{array}$ & $\begin{array}{c}\text { Aerobic digestion } \\
\text { batch lab-scale tests }\end{array}$ & $\begin{array}{l}68 \% \text { of protein degradation and } \\
66 \% \text { of VS after } 89 \text { days. }\end{array}$ & Shao et al., 2013 \\
\hline
\end{tabular}




\section{MATERIALS AND METHODS}

\section{2 \\ 2.1. Substrates studied}

113 Experiments were carried out in Spain with seven different waste streams, six liquid 114 effluents (S1 - S6), and one solid waste (S7). These waste streams were: S1, low-load

115 stream resultant from the mixture of dairy industry wastewater from milk production, cleaning effluents and urban sewage from office buildings and changing rooms; $\mathrm{S} 2$, dairy industry wastewater from condensed milk production; S3, anaerobic digestion effluent from an urban wastewater treatment plant (WWTP) with thermal hydrolysis pre-treatment; S4, the digested organic fraction of municipal solid waste (OFMSW) from an anaerobic membrane bioreactor (AnMBR) located in a metropolitan plant for integral waste treatment; S5, saline and low-load fish-canning industry wastewater resultant of the washing effluents of the factory; S6, high load fish-canning industry wastewater from mussel cookers, and S7, a mixture of primary (70 \%) and secondary (30 \%) sludge from an urban WWTP. To validate the proposed methodology, four additional substrates $(\mathrm{SC} 1-\mathrm{SC} 4)$ were tested in Chile following the same procedures considered in section 2 . The waste streams were: SC1, wine industry wastewater; SC2, tobacco industry wastewater; SC3, wastewater from a chipboard factory that uses ureaformaldehyde as glue; and SC4,slaughterhouse wastewater.

The substrates studied were very diverse regarding both origin and complexity. They were characterized by different COD and nitrogen concentrations, alkalinity, organic matter composition, and biodegradability to cover a broad range of compositions. Their distinctive properties, especially those that could affect the performance of BMP tests and COD fractionation assays are shown in Table 3 (see more details in Table S4 of Supplementary Material). 


\begin{tabular}{|c|c|c|c|c|c|c|c|c|c|c|c|}
\hline \multirow{2}{*}{ Parameter } & \multicolumn{11}{|c|}{ Sample } \\
\hline & S1 & $\mathrm{S} 2$ & S3 & S4 & S5 & S6 & $\mathrm{S} 7$ & $\mathrm{SC} 1$ & $\mathrm{SC} 2$ & $\mathrm{SC} 3$ & $\mathrm{SC} 4$ \\
\hline $\mathrm{pH}$ & 7.1 & 4.3 & 8.4 & 8.4 & 6.3 & 5.3 & 6.7 & 6.90 & 8.70 & 7.40 & 6.90 \\
\hline TSS $-*$ TS $(\mathrm{g} / \mathrm{L})$ & $261 \pm 14$ & $333 \pm 10$ & $119 \pm 16$ & $270 \pm 13$ & $2,074 \pm 278$ & $2,686 \pm 245$ & $17,607 \pm 753$ & $2.01 \pm 0.34$ & $0.48 \pm 0.03$ & $0.31 \pm 0.02$ & $1.98 \pm 0.20$ \\
\hline $\operatorname{VSS}-* \operatorname{VS}(\mathrm{g} / \mathrm{L})$ & $237 \pm 12$ & $321 \pm 12$ & $74 \pm 3$ & $149 \pm 1$ & $1,440 \pm 100$ & $1,737 \pm 217$ & $14,723 \pm 605$ & $1.29 \pm 0.09$ & $0.44 \pm 0.01$ & $0.30 \pm 0.01$ & $1.73 \pm 0.01$ \\
\hline $\mathrm{COD}_{\mathrm{t}}(\mathrm{mg} / \mathrm{L})$ & $707 \pm 3$ & $3,214 \pm 31$ & $2,477 \pm 37$ & $5,349 \pm 61$ & $3,346 \pm 22$ & $17,360 \pm 370$ & $18,455 \pm 320$ & $4,520 \pm 51$ & $1,605 \pm 151$ & $820 \pm 10$ & $452 \pm 50$ \\
\hline $\mathrm{COD}_{\mathrm{S}}(\mathrm{mg} / \mathrm{L})$ & $388 \pm 6$ & $2,535 \pm 22$ & $2432 \pm 55$ & $5,135 \pm 40$ & $369 \pm 46$ & $16,707 \pm 81$ & $2,312 \pm 109$ & $3,020 \pm 103$ & $1,568 \pm 411$ & $310 \pm 14$ & $302 \pm 100$ \\
\hline Prot. (mg COD/L) & $146 \pm 4$ & $176 \pm 4$ & $339 \pm 20$ & $2,094 \pm 137$ & $60 \pm 3$ & $5,734 \pm 136$ & 7,638 & $36.30 \pm 2.24$ & $316.54 \pm 4.09$ & $29.70 \pm 5.28$ & $578.56 \pm 5.28$ \\
\hline Carb. (mg COD/L) & $16 \pm 0.5$ & $343 \pm 25$ & $266 \pm 12$ & $173 \pm 9$ & $17 \pm 0.3$ & $11,370 \pm 383$ & 9267 & $138.03 \pm 24.72$ & $306.88 \pm 55.75$ & $263.76 \pm 17.55$ & $32.31 \pm 4.71$ \\
\hline Lipids (mg COD/L) & $40 \pm 2$ & $160 \pm 29$ & BDL & BDL & BDL & $680 \pm 115$ & 795 & BDL & $6 \pm 1$ & BDL & BDL \\
\hline VFAs (mg COD/L) & 107 & 432 & 45 & 301 & 33 & 363 & 1,540 & 390 & 597 & 43 & 187 \\
\hline $\mathrm{TN}(\mathrm{mg} \mathrm{N} / \mathrm{L})$ & 16 & 19 & 1,476 & 4,544 & 23 & 1,094 & - & 8 & 602 & 85 & 312 \\
\hline TKN (mg/L) & - & - & - & - & - & - & 829 & - & - & - & - \\
\hline $\mathrm{NH}_{4}^{+}(\mathrm{mg} / \mathrm{L})$ & 0.71 & 0.82 & 1,375 & 4,366 & 13 & 50 & 96 & 1.29 & 543 & 29 & 189 \\
\hline $\mathrm{Cl}^{-}(\mathrm{mg} / \mathrm{L})$ & 180 & 61 & 177 & 3,339 & 14,724 & 12,902 & - & - & - & - & - \\
\hline $\mathrm{Na}^{+}(\mathrm{mg} / \mathrm{L})$ & 782 & 321 & 57 & 1.748 & 5,427 & 7,333 & _- & - & _- & - & _- \\
\hline
\end{tabular}

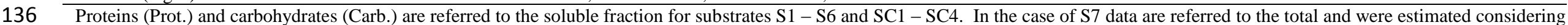

137 that: $\mathrm{VS}=$ carbohydrates + proteins + lipids; proteins $=6.25\left(\mathrm{TNK}-\mathrm{NH}_{4}{ }^{+}\right)$and $\mathrm{COD}=$ carbohydrates $\cdot 1.1+$ proteins $\cdot 1.3+$ lipids $\cdot 2.9 . \mathrm{BDL}($ below detection limit $)$.

$138 *$ In the case of S7 data are referred to TS and VS whereas in S1-S6 and SC1-SC4 data are referred to TSS and VSS, respectively. 


\subsection{Anaerobic biodegradability tests - Conventional BMP tests}

143 The BMP of the samples was determined by adapting the guidelines proposed by

144 Holliger et al. (2016).

145

146

147

\section{$\underline{\text { Test setup }}$}

Anaerobic biodegradability tests were carried out in triplicate in glass flasks of $500 \mathrm{~mL}$ (useful volume of $375 \mathrm{~mL}$ ) sealed with coiled butyl rubber stoppers and incubated in a temperature-controlled shaking bath under continuous mixing (New Brunswick Innova 4300, USA). Bottles were inoculated at a variable inoculum to substrate ratio (ISR) depending on the substrate characteristics (Table S1 of Supplementary Material) and filled up to the working volume with tap water. When necessary, part of the ammonium $\left(\mathrm{NH}_{4}^{+}\right)$present in the substrate was stripped out to avoid inhibitory FA concentrations. Thus, total ammoniacal nitrogen (TAN) concentrations above 1000-1500 mg/L have been reported as the primary cause of AD failure due to FA inhibition (Capson-Tojo et al., 2020). FA was calculated according to Anthonisen et al. (1976) from the $\mathrm{pH}$ and $\mathrm{NH}_{4}{ }^{+}$considering proteins hydrolyzation into $\mathrm{NH}_{4}{ }^{+}$concentration values. Stripping was carried out in aerated glass beakers at a $\mathrm{pH}$ of 10.0 ( $\mathrm{NaOH}$ addition) (Zhang et al., 2018) and $\mathrm{NH}_{4}{ }^{+}$and COD concentrations were periodically measured to determine the optimum pre-treatment time to obtain the needed $\mathrm{NH}_{4}{ }^{+}$stripping without significant COD removal (under $5 \%$ of the initial COD). $\mathrm{NH}_{4}^{+}$in the substrate was never completely removed since nitrogen is needed for microbial growth.

Prior to BMP tests performance, the inoculum was degassed $\left(37^{\circ} \mathrm{C}\right.$ and continuous mixing) in order to deplete the residual biodegradable organic material. Neither any growth media nor buffer was added thus the inoculum together with the tap water, provided an important source of macro- and micro-nutrients, trace elements, vitamins, 
and $\mathrm{pH}$-buffering capacity (inoculum alkalinity was higher than $3 \mathrm{~g} \mathrm{CaCO}_{3} / \mathrm{L}$ ). Before setting up the BMP tests, $\mathrm{pH}$ was measured and adjusted with $\mathrm{NaOH}$ or $\mathrm{HCl}$ solutions. Test experimental conditions for each substrate are outlined in Table S1 of Supplementary Material. In addition, blank assays with tap water and no substrate were carried out under the same conditions as their respective BMP tests to know the background methane production from the inoculum. Once prepared, the bottles were flushed with pure $\mathrm{N}_{2}$ for $1-3$ min to ensure anaerobic conditions prior to the start-up of the tests.

The volume of biogas produced was determined by the variation of pressure in the headspace of the glass flask by means of a pressure transducer (Centrepoint Electronics, UK) and the biogas composition was measured by gas chromatography (5890A Hewlett Packard, USA). Tests were terminated when the daily methane production during three consecutive days varied less than $1 \%$ of the accumulated volume of methane.

\section{$\underline{\text { Calculations }}$}

The experimental ultimate volume of methane produced was determined by subtracting the methane production of the blank from the methane production of the substrate. The BMP of the substrate (as $\mathrm{mL} \mathrm{CH}_{4} / \mathrm{g} \mathrm{COD}$ ) was calculated from the ultimate volume of methane produced under standard conditions $\left(0{ }^{\circ} \mathrm{C}\right.$ and $\left.1,013 \mathrm{hPa}\right)$ divided by the grams of $\mathrm{COD}_{\mathrm{t}}$ (total chemical oxygen demand) initially introduced as substrate $\left(\mathrm{COD}_{\mathrm{fed}}\right)$ in the flask (equation 1). Anaerobic biodegradability (as \%) was determined by dividing the BMP by the theoretical maximum methane yield of $350 \mathrm{~mL} \mathrm{CH}_{4} / \mathrm{g} \mathrm{COD}\left(0{ }^{\circ} \mathrm{C}\right.$ and 1,013 hPa) (equation 2) (Mottet et al., 2009). The fraction of COD converted into methane $\left(\mathrm{COD}_{\text {met }}\right)$ was calculated by equation 3 and the percentage of $\mathrm{CH}_{4}$ in the biogas was determined according to a German standard procedure (VDI 4630, 2016). 
$\operatorname{BMP}\left(\mathrm{mL} \mathrm{CH}_{4} / \mathrm{gCOD}_{\text {fed }}\right)=\mathrm{CH}_{4}$ produced $(\mathrm{mL}) / \mathrm{COD}_{\text {fed }}(\mathrm{g})$

Anaerobic biodegradability $(\%)=\mathrm{BMP}\left(\mathrm{mL} \mathrm{CH}_{4} / \mathrm{g} \mathrm{COD}_{\mathrm{fed}}\right) / 350\left(\mathrm{~mL} \mathrm{CH}_{4} / \mathrm{g} \mathrm{COD}\right) \cdot 100$

$\operatorname{COD}_{\text {met }}(\mathrm{g} / \mathrm{L})=($ Anaerobic biodegradability $) / 100 \cdot \mathrm{COD}_{\text {fed }}(\mathrm{g})$

191

192

193

194

2.3. COD fractionation: a combination of analytical determination and respirometric tests

\section{Definition of the COD fractions}

The total $\mathrm{COD}$ of the wastewater samples $\left(\mathrm{COD}_{\mathrm{t}}\right)$ was fractionated in its two major components; total biodegradable $\left(\mathrm{COD}_{\mathrm{b}}\right)$ and total inert $\left(\mathrm{COD}_{\mathrm{i}}\right)$. The $\mathrm{COD}_{\mathrm{b}}$ was further subdivided into soluble readily biodegradable $\left(\mathrm{S}_{\mathrm{b}}\right)$ and particulate slowly biodegradable $\left(\mathrm{X}_{\mathrm{b}}\right)$, whereas the $\mathrm{COD}_{\mathrm{i}}$ was subdivided into soluble inert $\left(\mathrm{S}_{\mathrm{i}}\right)$ and particulate inert $\left(\mathrm{X}_{\mathrm{i}}\right)$ (see Figure $\mathrm{S} 1$ of supplementary material). $\mathrm{COD}_{\mathrm{t}}\left(\right.$ sum of $\mathrm{COD}_{\mathrm{b}}$ and $\mathrm{COD}_{\mathrm{i}}$ ) and soluble chemical oxygen demand $\left(\mathrm{COD}_{\mathrm{s}}\right)$ (sum of $\mathrm{S}_{\mathrm{b}}$ and $\mathrm{S}_{\mathrm{i}}$ ) were analytically measured, while $\mathrm{COD}_{\mathrm{b}}$ and $\mathrm{S}_{\mathrm{b}}$ were individually determined by respirometric assays. Finally, $\mathrm{X}_{\mathrm{b}}, \mathrm{COD}_{\mathrm{i}}$, $\mathrm{S}_{\mathrm{i}}$, and $\mathrm{X}_{\mathrm{i}}$ were mathematically estimated.

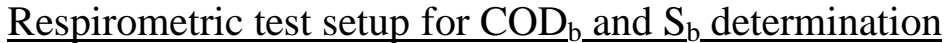

To determine $\mathrm{COD}_{\mathrm{b}}$ and $\mathrm{S}_{\mathrm{b}}$, the respirometric assays were done in triplicate in a completely mixed system (respirometer BM-T Plus 151204 Surcis, Spain), where the aeration and the peristaltic pump flow for recirculation were set on the required values according to the specifications given by the product manufacturer. The temperature was set at $25{ }^{\circ} \mathrm{C}$ and controlled by a thermostatic bath (PolyScience 16A01092, USA). During $\mathrm{COD}_{\mathrm{b}}$ and $\mathrm{S}_{\mathrm{b}}$ determination, the Surcis BM-T Plus 151204 respirometer measures in continuous mode the dissolved oxygen (DO) concentration and temperature 
and the associated software allows the simultaneous calculation and monitorization of other parameters: exogenous respiration rate $\left(\mathrm{R}_{\mathrm{s}}\right)\left(\mathrm{mg} \mathrm{O}_{2} / \mathrm{L} \cdot \mathrm{h}\right)$, specific $\mathrm{R}_{\mathrm{s}}\left(\mathrm{mg} \mathrm{O}_{2} / \mathrm{g}\right.$ VSS·h), consumed oxygen $(\mathrm{CO})\left(\mathrm{mg} \mathrm{O}_{2} / \mathrm{L}\right)$, substrate utilization rate (U) $(\mathrm{mg}$ $\mathrm{COD} / \mathrm{L} \cdot \mathrm{h})$ and specific $\mathrm{U}(\mathrm{mg} \mathrm{COD} / \mathrm{mg} \mathrm{SSV} \cdot \mathrm{h})$.

The respirometric tests were carried out with $1 \mathrm{~L}$ of sludge in the endogenous respiration phase with a concentration of solids between $1.5-5.0 \mathrm{~g}$ VSS/L and 2.0 - 5.0 $\mathrm{g}$ VSS/L for $\mathrm{COD}_{\mathrm{b}}$ and $\mathrm{S}_{\mathrm{b}}$ determination, respectively. The sludge was in each case previously diluted (in order to reach the optimum VSS concentrations) and conditioned if necessary (according to Table S3 of Supplementary Material). Allylthiourea (ATU) was added in concentrations between $2-3 \mathrm{mg}$ ATU/mg VSS, at least 30 minutes before the start-up of the assays in order to inhibit nitrification. For $\mathrm{COD}_{\mathrm{b}}$ determination, raw wastewater was added as a substrate. In the case of $S_{b}$ assays, samples with low colloidal content were centrifuged for 10 minutes at 7,500 rpm (Centrifuge 5430 Eppendorf, USA) and filtered (45 $\mu \mathrm{m}$ pore size, cellulose-ester membrane, Advantec, Japan). Samples with high colloidal content were coagulated in order to remove colloidal material and avoid interferences, settled and filtered by $45 \mu \mathrm{m}$. The volumes of substrate added in each case were selected as a function of their COD concentration according to the manufacturer specifications (Table S2 of Supplementary Material). The experimental conditions considered for each sample are shown in Table S3 of Supplementary Material. These assays were considered finished once the $R_{s}$ remained close to zero for a period no shorter than 10 minutes meaning that the biomass was under endogenous respiration conditions.

Heterotrophic growth yield (Y), expressed as $\mathrm{g}$ of COD produced as biomass per $\mathrm{g}$ of COD consumed as sodium acetate $\left(\mathrm{g} \mathrm{COD}_{\mathrm{X}} / \mathrm{g} \mathrm{COD}_{\mathrm{ac}}\right)$ for each experiment were determined under the same previously described operational conditions for 
respirometric assays with sodium acetate $(0.4 \mathrm{~g} / \mathrm{L}$ solution $)$ as substrate and considering a volume of $50 \mathrm{~mL}$ of this sodium acetate solution.

237 Calculation of $\mathrm{X}_{\underline{\mathrm{b}}}, \mathrm{COD}_{\mathrm{i}}, \underline{\mathrm{S}}_{\mathrm{i}}$ and $\mathrm{X}_{\mathrm{i}}$

$238 \mathrm{COD}_{\mathrm{b}}$ and $\mathrm{S}_{\mathrm{b}}$ fractions were experimentally determined through independent 239 respirometric assays from the $\mathrm{CO}$ in the total $\left(\mathrm{CO}_{\mathrm{t}}\right)$ and filtered sample $\left(\mathrm{CO}_{\mathrm{f}}\right)$ (equations 2404 and 5). The other COD fractions were calculated by equations $6-9$ considering the 241 analytically measured $\mathrm{COD}_{\mathrm{t}}$ and $\mathrm{COD}_{\mathrm{s}}$ concentrations and the results of the 242 respirometric assays for $\mathrm{COD}_{\mathrm{b}}$ and $\mathrm{S}_{\mathrm{b}}$ quantification.
$\mathrm{COD}_{\mathrm{b}}=\mathrm{CO}_{\mathrm{t}} /(1-\mathrm{Y})$
(4) $\quad \mathrm{S}_{\mathrm{b}}=\mathrm{CO}_{\mathrm{f}} /(1-\mathrm{Y})$
$\mathrm{X}_{\mathrm{b}}=\mathrm{COD}_{\mathrm{b}}-\mathrm{S}_{\mathrm{b}}$
(6) $\quad \mathrm{S}_{\mathrm{i}}=\mathrm{COD}_{\mathrm{s}}-\mathrm{S}_{\mathrm{b}}$
$\mathrm{COD}_{\mathrm{i}}=\mathrm{COD}_{\mathrm{t}}-\mathrm{COD}_{\mathrm{b}}$
$\mathrm{S}_{\mathrm{i}}=\mathrm{COD}_{\mathrm{i}}-\mathrm{S}_{\mathrm{i}}$

$243 \mathrm{Y}$ values were calculated by equation 10 considering the $\mathrm{CO}$ and the $\mathrm{COD}$ of the acetate 244 solution $\left(\mathrm{COD}_{\mathrm{ac}}\right)$ added as an organic matter source.

$245 \mathrm{Y}=1-\left(\mathrm{CO} / \mathrm{COD}_{\mathrm{ac}}\right)$

\subsection{Relationship between COD fractions and anaerobic biodegradability}

247 The average values of the obtained from triplicates (examples are shown in Figure S2 of

248 Supplementary Material) were used to find a relationship between the different COD 249 fractions measured in the samples and their anaerobic biodegradability. For that purpose, it were considered the $\mathrm{COD}_{\mathrm{b}}$ and their fractions $\left(\mathrm{S}_{\mathrm{b}}\right.$ and $\left.\mathrm{X}_{\mathrm{b}}\right)$ and the part of the COD initially introduced in the BMP bottles converted into methane ( $\left.\mathrm{COD}_{\text {met }}\right)$.

\subsection{Analytical methods}

$\mathrm{pH}$, conductivity, concentrations of $\mathrm{COD}_{\mathrm{t}}$, total Kjeldahl nitrogen $(\mathrm{TKN})$, proteins,

254 carbohydrates, lipids, total and total suspended solids (TS and TSS) and volatile and 
volatile suspended solids (VS and VSS) were measured in the raw samples. In addition, centrifuged (Centrifuge 5430 Eppendorf, USA) and filtered $(0.45 \mu \mathrm{m}$ pore size, cellulose-ester membrane, Advantec, Japan) samples were taken for the determination of other parameters in the soluble fraction: $\mathrm{COD}_{\mathrm{s}}$, volatile fatty acids (VFA), soluble carbohydrates, soluble proteins, total organic carbon (TOC), total nitrogen (TN), $\mathrm{NH}_{4}{ }^{+}$ and other ions $\left(\mathrm{Na}^{+}, \mathrm{Cl}^{-}, \mathrm{SO}_{4}^{-2}\right)$.

The $\mathrm{pH}$ was measured with a $\mathrm{pH} \&$ Ion-Meter GLP 22, Crison, (Spain), detection limit (DL): $-2-16$, conductivity with a probe Sension + EC5 HACH, (Spain), DL: $20.0-$ $150.0{ }^{\circ} \mathrm{C}, 1 \mu \mathrm{S} / \mathrm{cm}-200 \mathrm{mS} / \mathrm{cm}$, lipids by an extractive method using a Soxhlet extractor Jp Selecta 8001800, (Spain), TKN with a Kjeldahl digestion unit Gerhardt KB8S-VAP12, (Germany), TS, VS, TSS, and VSS concentrations were analyzed according to Standard Methods for the Examination of Water and Wastewater (APHA/AWWA/WEF, 2017). Concentrations of $\mathrm{COD}_{t}$ and $\mathrm{COD}_{\mathrm{s}}$ (ECO16 Thermoreactor VELP Scientifica, USA) were also measured according to APHA/AWWA/WEF (2017) but modified by (Taylor et al., 1989) when necessary, DL: $0-900 \mathrm{mg} / \mathrm{L}$. VFA were determined by gas chromatography (6850 Series II Agilent Technologies, USA; DL:1 - 1000 mg/L). Carbohydrates were measured by the Loewus method (Loewus, 1952) and expressed in equivalent glucose (Glu), DL: 0 - $90 \mathrm{mg} / \mathrm{L}$. Proteins were analyzed by the Lowry method (Lowry et al., 1951) and expressed in equivalent bovine serum albumin (BSA), DL: 0 - $2000 \mathrm{mg} / \mathrm{L}$. Concentrations of TOC and TN were measured by catalytic combustion in the TOC-L CNS analyzer with the TNM-1 module (TOC-5000 Shimazdu, Japan), DL: 0.5 - 1000 mg/L. Concentrations of $\mathrm{NH}_{4}{ }^{+}$were determined by the Bower/Holm Hansen method (Bower and Holm-Hansen, 1980), DL: $0-1 \mathrm{mg} / \mathrm{L}$. Concentrations of $\mathrm{Cl}^{-}, \mathrm{SO}_{4}{ }^{-2}$ and $\mathrm{Na}^{+}$were measured by ion 
279 chromatography (861 Advanced Compact IC Metrohm, Switzerland), DL: 1 - $100 \mathrm{mg}$ $280 \mathrm{Cl}^{-} / \mathrm{L}, 1.5-150 \mathrm{mg} \mathrm{SO}_{4}^{-2} / \mathrm{L}$ and $11.5-150 \mathrm{mg} \mathrm{Na}^{+} / \mathrm{L}$.

\section{RESULTS AND DISCUSSION}

\subsection{BMP prediction from COD fractionation}

The results of BMP tests and COD fractionation assays are summarized in Table 4 and

Figure 1, respectively. Additional information regarding COD fractions can be consulted in Table S5 of Supplementary Material.

Table 4. Results of the BMP tests.

\begin{tabular}{|c|c|c|c|c|}
\hline Substrate & $\begin{array}{c}\text { BMP } \\
\left(\mathrm{mL} \mathrm{CH}_{4} / \mathrm{g} \mathrm{COD}_{\mathrm{fed}}\right)\end{array}$ & $\begin{array}{c}\text { Anaerobic } \\
\text { biodegradability }(\%)\end{array}$ & $\begin{array}{c}\mathrm{CH}_{4} \text { in the biogas at } \\
\text { the end of the BMP } \\
\text { tests }(\%)\end{array}$ & $\begin{array}{l}\text { Lag phase } \\
\text { lenght (d) }\end{array}$ \\
\hline S1 & $218.37 \pm-7.48$ & $59.69 \pm 0.28$ & $72.37 \pm 0.80$ & 1 \\
\hline S2 & $264.68 \pm 2.24$ & $73.46 \pm 0.30$ & $84.22 \pm 1.48$ & 4 \\
\hline S3 & $63.55 \pm 0.54$ & $19.17 \pm 0.15$ & $72.95 \pm 0.66$ & 1 \\
\hline S4 & $182.46 \pm 10.23$ & $52.42 \pm 1.43$ & $62.84 \pm 1.72$ & 35 \\
\hline S5 & $165.92 \pm 10.34$ & $46.84 \pm 2.06$ & $80.99 \pm 0.25$ & $<1$ \\
\hline S6 & $293.32 \pm 11.78$ & $87.88 \pm 3.43$ & $72.51 \pm 0.83$ & 7 \\
\hline S7 & $237.02 \pm 7.79$ & $66.91 \pm 2.20$ & $67.92 \pm 2.08$ & 1 \\
\hline
\end{tabular}

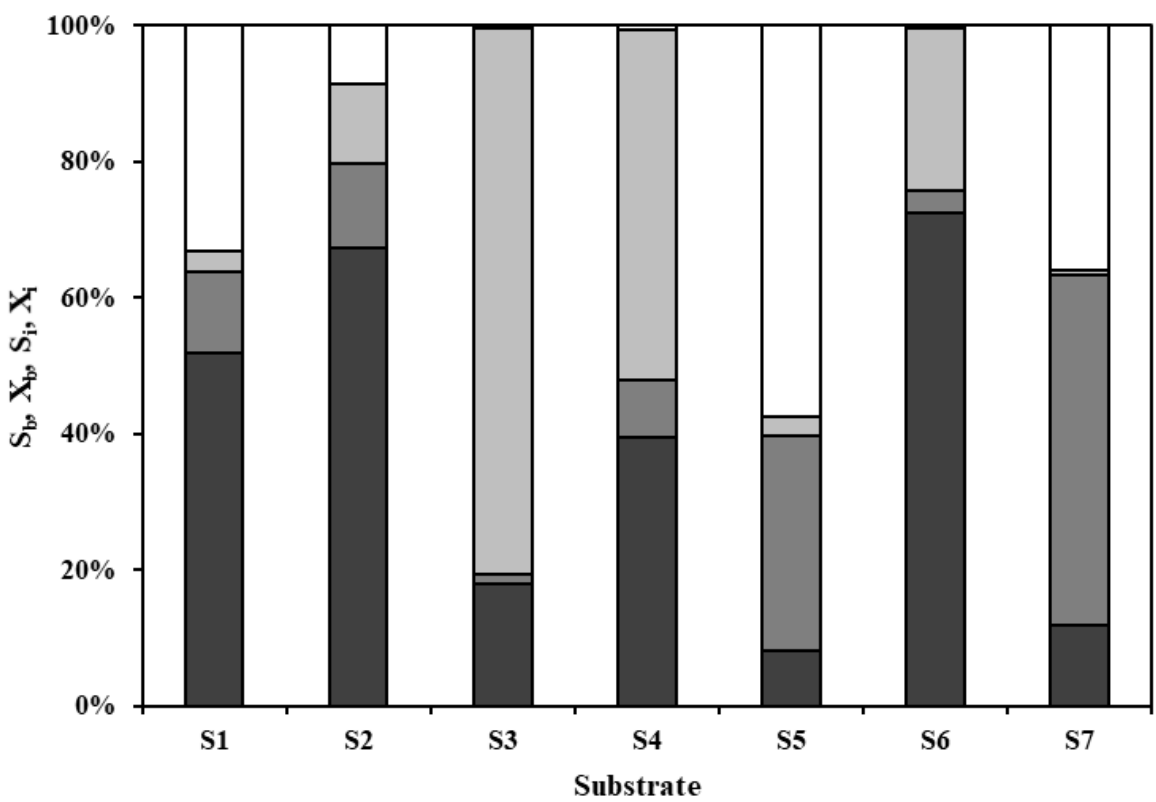

$(\square)$, particulate slowly biodegradable $\left(\mathrm{X}_{\mathrm{b}}\right)(\mathbf{m})$ and particulate inert $\left(\mathrm{X}_{\mathrm{i}}\right)(\square)$. 
The results obtained in the BMP tests and COD fractionation assays showed that the

293

294

295

296

297

298

299

300

301

302

303

304

305

307

308

309 anaerobically degraded COD of the samples $\left(\mathrm{COD}_{\text {met }}\right)$ almost corresponded to the biodegradable fraction of the $\mathrm{COD}\left(\mathrm{COD}_{\mathrm{b}}\right)$ (Figure 2). In this way, if there are no significant differences between $\mathrm{COD}_{\text {met }}$ and $\mathrm{COD}_{\mathrm{b}}, \mathrm{COD}_{\mathrm{b}}$ might be feasibly used as a BMP predictor. Thus, if $\mathrm{COD}_{\mathrm{b}}$ equals to $\mathrm{COD}_{\text {met }}$ and $1 \mathrm{~g}$ of $\mathrm{COD}$ produces a maximum of $350 \mathrm{~mL}$ of $\mathrm{CH}_{4}\left(0{ }^{\circ} \mathrm{C}\right.$ and $\left.1,013 \mathrm{hPa}\right)$, then the produced volume of $\mathrm{CH}_{4}$ would correspond to the product between $\mathrm{COD}_{\mathrm{b}}$ and $350 \mathrm{~mL} \mathrm{CH} / \mathrm{COD}_{\text {fed. }}$ Therefore, once estimated the $\mathrm{mL}$ of $\mathrm{CH}_{4}$ produced, the BMP of a substrate can be calculated according to equation (1) by dividing the volume of $\mathrm{CH}_{4}$ by the COD fed as a substrate in the pertinent COD fractionation assay. This would allow for a reliable calculation of biomethane producibility in few hours (COD fractionation assays time in this study), compared to many days (conventional BMP tests usually take from 20 to more than 100 days).

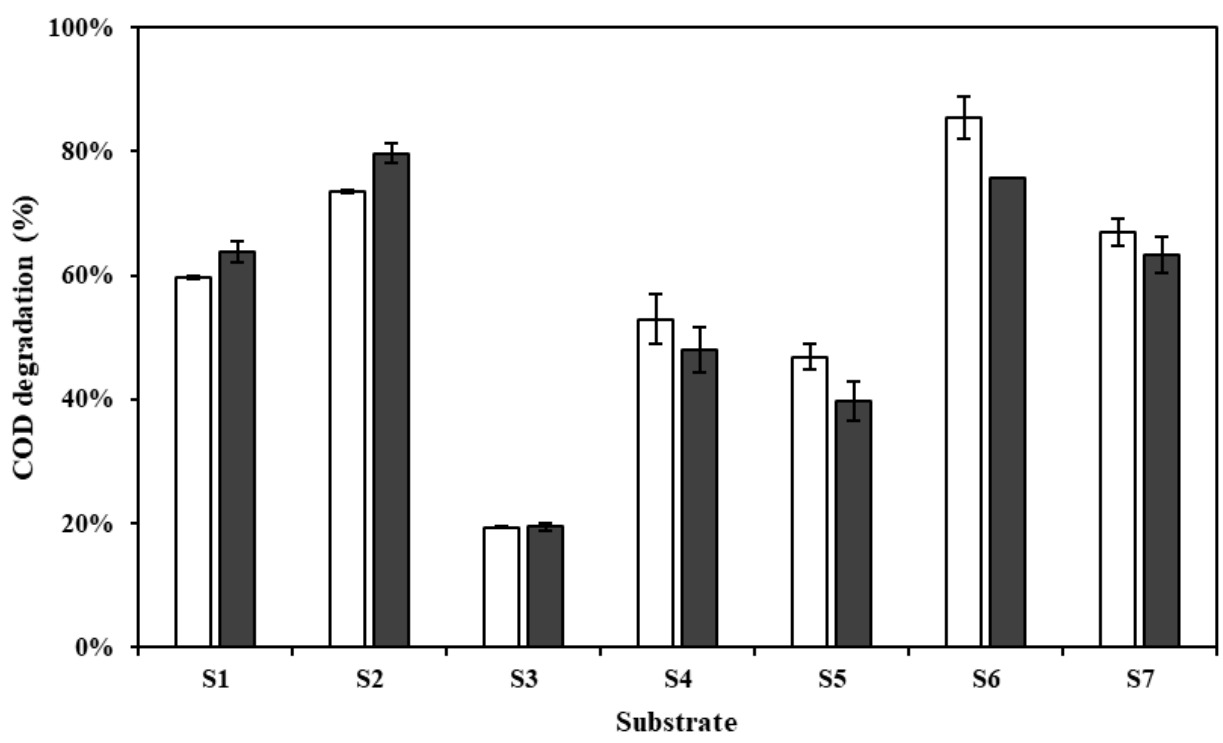

Figure 2. Percentages of $\mathrm{COD}_{\text {met }}(\square)$ and $\mathrm{COD}_{b}(\boldsymbol{\square})$ for each substrate.

Average experimental results obtained by both methodologies (BMP tests and COD fractionation assays) were statistically compared (t-test for independent samples at $5 \%$ significance level) using SPSS software (IBM Corp. Released 2017. IBM SPSS 
310 Statistics for Windows, Version 25.0. Armonk, NY: IBM Corp.) in terms of percentage 311 of substrate biodegraded. The Shapiro-Wilk normality test showed normal data 312 distributions $\left(\mathrm{p}_{1}=0.863, \mathrm{p}_{2}=0.647\right)$ and according to Levene's test, there was no 313 homogeneity of variances. Considering this results, significant differences between 314 BMP tests $(57.8026 \pm 21.2875)$ and COD fractionation assays results $(55.6491 \pm$ 315 21.3417) were not detected, $\mathrm{t}(5)=0.189, \mathrm{p}=0.853$. Besides, it was built mathematical 316 models based on linear regressions using SPSS software considering all the COD 317 fractions. The models with the best correlation were those that included all the 318 biodegradable COD fractions as $\mathrm{COD}_{\mathrm{b}}$ or as the sum of the $\mathrm{S}_{\mathrm{b}}$ and $\mathrm{X}_{\mathrm{b}}$ (Table S6 of 319 Supplementary Material). The one with the highest $\mathrm{R}^{2}$ and lowest SE was model M7: $320 \mathrm{COD}_{\mathrm{met}}=1.125 \cdot \mathrm{S}_{\mathrm{b}}+1.041 \cdot \mathrm{X}_{\mathrm{b}}\left(\mathrm{R}^{2}=0.999 ; \mathrm{SE}=237\right)$ although the one that only 321 considers $\mathrm{COD}_{\mathrm{b}}, \mathrm{M} 1: \mathrm{COD}_{\mathrm{met}}=1.094 \cdot \mathrm{COD}_{\mathrm{b}}\left(\mathrm{R}^{2}=0.998 ; \mathrm{SE}=318\right)$ seemed to be accurate enough to early predict the BMP of a substrate, which suggests that there is no need for performing the whole COD fractionation. In fact, M1 can be simplified as $\mathrm{COD}_{\text {met }}=\mathrm{COD}_{\mathrm{b}}$ (thus no significant differences were detected between $\mathrm{COD}_{\text {met }}$ results predicted by M1 and simplified M1).

326 To corroborate the accuracy of using the $\mathrm{COD}_{\mathrm{b}}$ of a substrate to early predict its BMP, it was carried out an inter-laboratory study with four additional substrates (SC1-SC4). The results obtained in BMP tests and COD fractionation assays are summarised in Table S7 of Supplementary Material. According to Figure 3 these four additional experiences fit 330 the simplified M1 model predicted from substrates S1-S7, which validates the proposed methodology. 


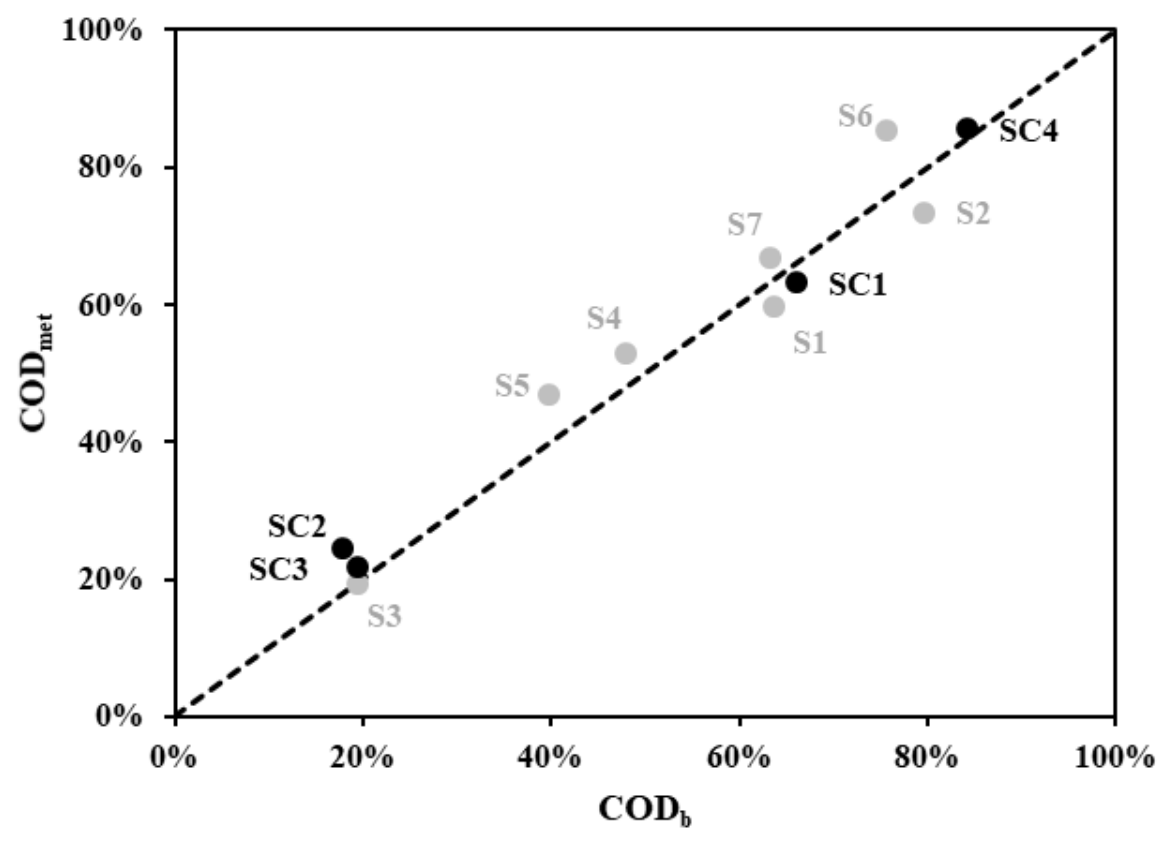

332

Figure 3. Degree of approximation to the predicted correlation $\mathrm{COD}_{\mathrm{met}}=\mathrm{COD}_{\mathrm{b}}(---)$ of substrates tested in

$$
\text { Spain }(\mathrm{S} 1-\mathrm{S} 7)(\bullet) \text { and Chile }(\mathrm{SC} 1-\mathrm{SC} 4)(\bullet) \text {. }
$$

\subsection{Substrates particularities affecting the degree of correlation between $\mathrm{COD}_{\text {met }}$} and $\mathrm{CDO}_{\mathrm{b}}$

Although the potentially biodegraded organic matter seemed almost the same independently of the conditions (anaerobic or aerobic), the degree of similarity between $\mathrm{COD}_{\text {met }}$ and $\mathrm{COD}_{\mathrm{b}}$ varied depending on the substrate characteristics (Figure 2). The influence of certain particularities of the samples over the performance of the anaerobic and aerobic assays, as well as the effect of the type of inocula used will be discussed in this section. For that purpose, it was considered the samples from which was initially predicted the correlation between $\mathrm{COD}_{\text {met }}$ and $\mathrm{COD}_{\mathrm{b}}$ (substrates $\mathrm{S} 1-\mathrm{S} 7$ ).

S1 presented an anaerobic biodegradability of $59.69 \pm 0.28 \%$ (Table 4) and COD fractionation showed that $63.77 \pm 1.61 \%$ of the COD was biodegradable being the $81.37 \%$ of the $\mathrm{COD}_{\mathrm{b}}$ soluble and readily biodegradable (Figure 1). In the fractionation assays of $\mathrm{COD}$, it was observed that $\mathrm{COD}_{\mathrm{b}}$ was rapidly consumed when using sludge 
from a bioreactor treating the same effluent because biomass was already acclimated to the tested substrate. However, when using conventional activated sludge from an urban WWTP it was reached negative $R_{s}$ values at the end of the tests, which indicated a drastic drop in the active biomass (data not shown). This negative effect may be due to the presence of toxic compounds in the wastewater, probably sodium hypochlorite $(\mathrm{NaClO})$ or caustic soda $(\mathrm{NaOH})$ (according to $\mathrm{Na}^{+}$concentrations, Table 3), washing agents typically used in dairy industry cleaning in place (CIP) systems (Hung et al., 2010). In general, aerobic microorganisms are less resistant to toxic and inhibitory compounds, which can derive on a lower aerobic biodegradability of the substrates as occurred with S1 (Al Momani et al., 2010; Amaral et al., 2015). Therefore, the use of a sludge acclimated to certain compounds that could hinder the performance of the respirometric tests, might avoid inhibition and allow for higher accuracy of the methodology.

S2 had an anaerobic biodegradability of $73.46 \pm 0.30 \%$ (Table 4). COD fractionation showed that $79.68 \pm 1.63 \%$ of the COD was biodegradable, being the $84.45 \%$ of $\mathrm{COD}_{\mathrm{b}}$ soluble and readily biodegradable $(84.45 \%)$ (Figure 1$). \mathrm{X}_{\mathrm{b}}(15.55 \%)$ were primarily colloids, which needed to be removed before $S_{b}$ determination to avoid interferences. For this purpose, the wastewater was flocculated by the addition of $100 \mathrm{mg} / \mathrm{L}$ of $\mathrm{Al}_{2}\left(\mathrm{SO}_{4}\right)_{3}$ during $2 \mathrm{~h} 30 \mathrm{~min}$ of severe stirring, then $20 \mathrm{~min}$ of gentle stirring and finally 20 min of settling.

Substrate S3 presented the lowest BMP and hence anaerobic biodegradability $(19.17 \pm$ $0.15 \%)$ (Table 4) and the lowest percentage of $\operatorname{COD}_{\mathrm{b}}(19.42 \pm 0.62 \%)$, which was mostly soluble $(92.78 \%)$ and readily biodegradable (Figure 1). It was the effluent of an anaerobic digester from a WWTP treating a mixture of primary and secondary sludge and the biodegradation of the $20 \%$ of the initial COD almost corresponded with the 
373 fraction of non-hydrolized proteins and carbohydrates (Table 3). This substrate showed 374 the strongest correspondence between $\mathrm{COD}_{\text {met }}$ and $\mathrm{COD}_{\mathrm{b}}$ (Figure 2). Due to its origin, it 375 should not have adaptation problems with the anaerobic inoculum used since it was 376 collected from a lab-scale anaerobic reactor fed with secondary sludge from an urban 377 WWTP. In the case of the aerobic assays, the $\mathrm{COD}_{\mathrm{b}}$ mainly corresponded with the sum 378 of readily biodegradable substances that could be easily consumed by activated sludge.

Substrate S4 had a potential risk of AD inhibition by FA due to its high $\mathrm{NH}_{4}{ }^{+}$and protein concentration. Consequently, before BMP tests performance, part of the $\mathrm{NH}_{4}{ }^{+}$ was stripped reaching an anaerobic biodegradability of $52.42 \pm 1.43 \%$ (Table 4). It was obtained a slightly lower $\mathrm{COD}_{\mathrm{b}}$ percentage of $47.90 \pm 3.65 \%$ (Figure 1), which almost corresponded with the VFAs, proteins, and carbohydrates measured in the soluble fraction (Table 3). Although in respirometric assays COD consumption rapidly started, BMP tests showed a long lag phase and biomethane production was not detected until 35 days after the start-up of the assay. This could be related to the use of a non-adapted inoculum and/or to the presence of unknown compounds. Thus, substrates with a similar origin to S4 are very complex and commonly contain very diverse toxic and nontoxic organic substances, xenobiotics, heavy metals, etc. (Youcai, 2018), which could be present but were not measured here.

S5 and S6 were the substrates with the greatest differences between their anaerobic and aerobic biodegradabilities (Figure 2). Anaerobic biodegradabilities were $46.84 \pm 2.06$ and $87.88 \pm 3.43$ (Table 4) whereas respirometric assays showed $\mathrm{COD}_{\mathrm{b}}$ percentages of $40 \%$ and $76 \%$ for S5 and S6 (Figure 1), respectively. The main distinctive characteristic of S5 and S6 was their high salinity content, approximately $20 \mathrm{~g} \mathrm{NaCl} / \mathrm{L}$. However, differences observed between $\mathrm{COD}_{\mathrm{b}}$ and $\mathrm{COD}_{\text {met }}$ did not seem to be a consequence of inhibition by salinity since both tests were carried out with acclimated 
inocula. It seems that high $\mathrm{NaCl}$ concentrations affected the response of the oxygen probe sensor since in both cases, anaerobic biodegradability was lower (despite the higher substrate concentration in the anaerobic tests), and differences were more significant for $\mathrm{S} 5$, which had a higher $\mathrm{NaCl}$ content. In the case of substrates $\mathrm{S} 5$ and $\mathrm{S} 6$ it was observed an additional hindrance. The sludge took a long time to reach the endogenous respiration phase. This fact could be due to the presence of remaining slowly biodegradable COD in the sludge. To overcome this problem, the sludge was washed with water containing $\mathrm{NaCl}$ concentrations similar to those of the sludge. to avoid an osmotic shock in the biomass because of $\mathrm{NaCl}$ absence.

S7 presented an anaerobic biodegradability of $66.91 \pm 2.20$ (Table 4). COD fractionation showed a similar aerobic biodegradability $(63.31 \pm 4.53 \%)$ being $81.21 \%$ of the $\mathrm{COD}_{\mathrm{b}}$ particulate and slowly biodegradable, which correlated with the nature of the substrate and the large duration of the respirometric assays (Figure 1). This $X_{b}$ fraction consisted of substances present in the influent and separated in the primary decanters (primary sludge) or generated in the activated sludge reactor of the WWTP and separated in the secondary decanters (secondary sludge) (Ekama et al., 2007). Besides, more than $98 \%$ of the non-biodegradable organics were particulate. Ekama et al. (2007) observed that this type of particulate organics were both unbiodegradable under anaerobic (anaerobic digestion process) and aerobic conditions (fully aerobic or nitrogen removal activated sludge system), which correlates with the results obtained in the present study. It should be also pointed out that the respirometer used was not specifically designed for solid substrates and long-term assays. Consequently, although reproducible results were observed, possible destabilization problems throughout time could affect the performance of the tests. 
424 According to the previously exposed results, the determination of $\mathrm{COD}_{\mathrm{b}}$ by $\mathrm{COD}$

425 fractionation assays seems to be a good alternative to predicting the BMP of substrates,

426 reducing the testing time from weeks-months (conventional BMP) to hours.

427 The COD fractionation tests are inexpensive and easy to perform, even if compared 428 with other alternative methods such as spectroscopic techniques (Jingura and 429 Kamusoko, 2017) or mathematical models. Moreover, this respirometric method can be 430 implemented with diverse substrates both liquid (different complexity liquid effluents) and solid (sewage sludge), whereas previously developed alternative methodologies were mainly focused on solid feedstocks (Table 1). Furthermore, in the COD fractionation experiments, it is possible to biodegrade the slowly biodegradable organic matter as observed in SC3 COD fractionation test, the effluent of a chipboard factory containing slowly biodegradable lignocellulosic materials. Other respirometric tests like the aerobic tests, do not offer the advantage of breaking down complex organic compounds (Lesteur et al., 2010). In fact, the Biological Oxygen Demand (BOD) presents a strong correlation with the BMP but not when considering substrates with high lignin content. Besides, these aerobic tests are time-consuming in comparison to COD fractionation assays (Bayard et al., 2016; Cossu and Raga, 2008; Ponsá et al., 2008)

However, especially when working with complex substrates, it is necessary to have a high activity inoculum capable of consuming all the biodegradable fraction of a substrate without being affected by the presence of toxic or inhibitory substances. This aspect might be a drawback if there is not an available adapted sludge since its progressive adaptation would significantly extend testing time. Another negative time- 
consuming aspect is that on occasions (e.g. S5), the degradation of all the exogenous substrate initially present in the sludge takes a long time through just aerating the biomass before performing the tests. In these cases, the sludge could be previously washed to reduce most of the initial slowly biodegradable COD concentration present on it (Dircks et al., 1999; Zerdazi et al., 2012).

452 Despite the good correlation obtained between $\mathrm{COD}_{\mathrm{b}}$ and $\mathrm{COD}_{\text {met }}$ and the advantages of 453 using COD fractionation for BMP prediction, the COD fractionation procedure described in this paper is not the only option for determining the $\operatorname{COD}_{\mathrm{b}}$. of a substrate There are very different devices available in the market and several protocols. Nonetheless, as long as a methodology allows for the determination of all the biodegradable COD (including the slowly biodegradable and particulate fraction), this could be able to predict the BMP of a substrate. In this regard, further investigation is recommended to evaluate the applicability of different methodologies to other datasets of $\mathrm{COD}_{\mathrm{b}}$ and BMP. In special, when considering complex substrates with a slow biodegradability and solid streams.

\section{CONCLUSIONS}

Biodegradability results obtained through BMP $\left(\mathrm{COD}_{\text {met }}\right)$ and $\mathrm{COD}$ fractionation assays

$465\left(\mathrm{COD}_{\mathrm{b}}\right)$ did not significantly differ in the tested substrates despite their diverse origin, complexity, and characteristics. Each substrate presented a certain biodegradability and when considering adapted microorganisms as inocula, appropriate operational conditions and the necessary biodegradation time (thus kinetics are different), the biodegraded organic matter was nearly the same under anaerobic and aerobic conditions. In fact, it was proven that it was possible to predict the BMP of a substrate 
471 by just performing a single respirometric test for $\mathrm{COD}_{\mathrm{b}}$ determination without the need

472 of considering the other COD fractions. The accuracy and versatility of this less time473 consuming methodology were validated by means of an inter-laboratory comparison 474 considering four additional substrates.

475

\section{ACKNOWLEDGEMENTS}

477

This research was supported by the Spanish Government (AEI) through the

TREASURE project [CTQ2017-83225-C2-1-R]. Moreover, authors would like to thank the EU and the AEI for funding, in the frame of the collaborative international Consortium AquaVal project, [PCIN-2017-047], financed under the ERA-NET

WaterWorks2015 Co-funded Call. This ERA-NET is an integral part of the 2016 Joint Activities developed by the Water Challenges for a Changing World Joint Programme Initiative (Water JPI). Authors from the USC belong to the Galician Competitive Research Group GRC ED431C 2017/29. All these programs are co-funded by the FEDER (EU). Lucia Argiz is a Xunta de Galicia Fellow (2019), Axudas de Apoio á Etapa Predoutoral (ED481A-2019/083), grant cofounded by the operative program FSE Galicia 2014-2020. In addition, this work was funded by the Chilean Government through the projects FONDECYT 1180650 and CONICYT/FONDAP/15130015. Marisol Belmonte belongs to LABMAI-Facultad de Ingeniería, HUB-Ambiental UPLA and UPLAguas Research Group.

\section{REFERENCES}

Al Momani, F.A., Shawaqfeh, A.T., Al-Zoubi, H., 2010. Comparison of different treatment alternatives for removal of pesticide from water solution. J. Chem. Technol. Biotechnol. 85, 529-535. https://doi.org/10.1002/jctb.2324

Amaral, M.C.S., Andrade, L.H. de, Lange, L.C., Borges, C.P., 2015. Avaliação da 

biotratabilidade do efluentede branqueamento de polpa celulósicapor processos aeróbios e anaeróbios. Eng. Sanit. e Ambient. 18, 253-262. https://doi.org/10.1590/s141341522013000300008

APHA/AWWA/WEF, 2017. Standard Methods for the Examination of Water and Wastewater, 23rd ed., American Public Health Association, Washingto, DC, USA. Am. Public Heal. Assoc. Washingto, DC, USA. https://doi.org/ISBN 9780875532356

Astals, S., Esteban-Gutiérrez, M., Fernández-Arévalo, T., Aymerich, E., García-Heras, J.L., Mata-Alvarez, J., 2013. Anaerobic digestion of seven different sewage sludges: A biodegradability and modelling study. Water Res. 47, 6033-6043. https://doi.org/10.1016/j.watres.2013.07.019

Banja, M., Sikkema, R., Jégard, M., Motola, V., Dallemand, J.F., 2019. Biomass for energy in the EU - The support framework. Energy Policy 131, 215-228. https://doi.org/10.1016/j.enpol.2019.04.038

Bayard, R., Liu, X., Benbelkacem, H., Buffiere, P., Gourdon, R., 2016. Can Biomethane Potential (BMP) Be Predicted from Other Variables Such As Biochemical Composition in Lignocellulosic Biomass and Related Organic Residues? Bioenergy Res. 9, 610-623. https://doi.org/10.1007/s12155-015-9701-3

Bekiaris, G., Triolo, J.M., Peltre, C., Pedersen, L., Jensen, L.S., Bruun, S., 2015. Rapid estimation of the biochemical methane potential of plant biomasses using Fourier transform mid-infrared photoacoustic spectroscopy. Bioresour. Technol. 197, 475-481. https://doi.org/10.1016/j.biortech.2015.08.050

Bellaton, S., Guérin, S., Pautremat, N., Bernier, J., Muller, M., Motellet, S., Azimi, S., Pauss, A., Rocher, V., 2016. Early assessment of a rapid alternative method for the estimation of the biomethane potential of sewage sludge. Bioresour. Technol. 206, 279-284. https://doi.org/10.1016/j.biortech.2016.01.139

Bower, C.E., Holm-Hansen, T., 1980. A Salicylate-Hypochlorite Method for Determining Ammonia in Seawater. Can. J. Fish. Aquat. Sci. 37, 794-798. https://doi.org/10.1139/f80106

Browne, J.D., Murphy, J.D., 2013. Assessment of the resource associated with biomethane from food waste. Appl. Energy 104, 170-177. https://doi.org/10.1016/j.apenergy.2012.11.017

Capson-Tojo, G., Moscoviz, R., Astals, S., Robles, Steyer, J.P., 2020. Unraveling the literature chaos around free ammonia inhibition in anaerobic digestion. Renew. Sustain. Energy Rev. 117, 109487. https://doi.org/10.1016/j.rser.2019.109487

Chen, Y., Cheng, J.J., Creamer, K.S., 2008. Inhibition of anaerobic digestion process: A review. 
Cossu, R., Raga, R., 2008. Test methods for assessing the biological stability of biodegradable waste. Waste Manag. 28, 381-388. https://doi.org/10.1016/j.wasman.2007.01.014

Da Silva, C., Astals, S., Peces, M., Campos, J.L., Guerrero, L., 2018. Biochemical methane potential (BMP) tests: Reducing test time by early parameter estimation. Waste Manag. 71, 19-24. https://doi.org/10.1016/j.wasman.2017.10.009

Dandikas, V., Heuwinkel, H., Lichti, F., Drewes, J.E., Koch, K., 2018. Predicting methane yield by linear regression models: A validation study for grassland biomass. Bioresour. Technol. 265, 372-379. https://doi.org/10.1016/j.biortech.2018.06.030

Del Pozo, R., Taş, D.O., Dulkadiroğlu, H., Orhon, D., Diez, V., 2003. Biodegradability of slaughterhouse wastewater with high blood content under anaerobic and aerobic conditions. J. Chem. Technol. Biotechnol. 78, 384-391. https://doi.org/10.1002/jctb.753

Dircks, K., Pind, P.F., Mosbæk, H., Henze, M., 1999. Yield determination by respirometry The possible influence of storage under aerobic conditions in activated sludge. Water SA $25,69-74$.

Ekama, G.A., Sötemann, S.W., Wentzel, M.C., 2007. Biodegradability of activated sludge organics under anaerobic conditions. Water Res. 41, 244-252. https://doi.org/10.1016/j.watres.2006.08.014

El Hajjouji, H., Barje, F., Pinelli, E., Bailly, J.R., Richard, C., Winterton, P., Revel, J.C., Hafidi, M., 2008. Photochemical UV/TiO2 treatment of olive mill wastewater (OMW). Bioresour. Technol. 99, 7264-7269. https://doi.org/10.1016/j.biortech.2007.12.054

Elefsiniotis, P., Wareham, D.G., 2013. Biodegradation of industrial-strength 2,4dichlorophenoxyacetic acid wastewaters in the presence of glucose in aerobic and anaerobic sequencing batch reactors. Environ. Technol. (United Kingdom) 34, 1167-1174. https://doi.org/10.1080/09593330.2012.743590

Feng, L., Li, Y., Chen, C., Liu, X., Xiao, X., Ma, X., Zhang, R., He, Y., Liu, G., 2013. Biochemical methane potential (BMP) of vinegar residue and the influence of feed to inoculum ratios on biogas production. BioResources 8, 2487-2498. https://doi.org/10.15376/biores.8.2.2487-2498

Godin, B., Mayer, F., Agneessens, R., Gerin, P., Dardenne, P., Delfosse, P., Delcarte, J., 2015. Biochemical methane potential prediction of plant biomasses: Comparing chemical composition versus near infrared methods and linear versus non-linear models. Bioresour. Technol. 175, 382-390. https://doi.org/10.1016/j.biortech.2014.10.115 
Gunaseelan, V.N., 2004. Biochemical methane potential of fruits and vegetable solid waste feedstocks. Biomass and Bioenergy 26, 389-399. https://doi.org/10.1016/j.biombioe.2003.08.006

Holliger, C., Alves, M., Andrade, D., Angelidaki, I., Astals, S., Baier, U., Bougrier, C., Buffière, P., Carballa, M., de Wilde, V., Ebertseder, F., Fernández, B., Ficara, E., Fotidis, I., Frigon, J.-C., de Laclos, H.F., Ghasimi, D.S.M., Hack, G., Hartel, M., Heerenklage, J., Horvath, I.S., Jenicek, P., Koch, K., Krautwald, J., Lizasoain, J., Liu, J., Mosberger, L., Nistor, M., Oechsner, H., Oliveira, J.V., Paterson, M., Pauss, A., Pommier, S., Porqueddu, I., Raposo, F., Ribeiro, T., Rüsch Pfund, F., Strömberg, S., Torrijos, M., van Eekert, M., van Lier, J., Wedwitschka, H., Wierinck, I., 2016. Towards a standardization of biomethane potential tests. Water Sci. Technol. 74, 2515-2522. https://doi.org/10.2166/wst.2016.336

Howell, G., Bennett, C., 2019. A comparison of methods for early prediction of anaerobic biogas potential on biologically treated municipal solid waste 232, 887-894. https://doi.org/10.1016/j.jenvman.2018.11.137

Hung, Y.-T., Britz, T., van Schalkwyk, C., 2010. Treatment of Dairy Processing Wastewaters. Waste Treat. Food Process. Ind. 1-28. https://doi.org/10.1201/9781420037128.ch1

Jarde, E., Mansuy, L., Faure, P., 2003. Characterization of the macromolecular organic content of sewage sludges by thermally assisted hydrolysis and methylation-gas chromatographymass spectrometer (THM-GC/MS). J. Anal. Appl. Pyrolysis 68-69, 331-350. https://doi.org/10.1016/S0165-2370(03)00053-6

Jingura, R.M., Kamusoko, R., 2017. Methods for determination of biomethane potential of feedstocks: a review. Biofuel Res. J. 4, 573-586. https://doi.org/10.18331/brj2017.4.2.3

Kianmehr, P., Mansoor, W., Kfoury, F.A., 2013. Prediction of Biogas Generation Profiles in Wastewater Treatment Plants Using Neural Networks. J. Clean Energy Technol. 2, 201205. https://doi.org/10.7763/jocet.2014.v2.123

Lesteur, M., Bellon-Maurel, V., Gonzalez, C., Latrille, E., Roger, J.M., Junqua, G., Steyer, J.P., 2010. Alternative methods for determining anaerobic biodegradability: A review. Process Biochem. 45, 431-440. https://doi.org/10.1016/j.procbio.2009.11.018

Loewus, F.A., 1952. Improvement in Anthrone Method for Determination of Carbohydrates Errors in Volumetric Analysis Arising from Adsorption. Anal. Chem. 24, 219-219. https://doi.org/10.1021/ac60061a050

Lowry, O. H.; Rosebrough, N. J.; Farr, A. L.; Randall, R.J., 1951. The folin by oliver. Anal. Biochem. 217, 220-230. https://doi.org/10.1016/0304-3894(92)87011-4 
Malico, I., Nepomuceno Pereira, R., Gonçalves, A.C., Sousa, A.M.O., 2019. Current status and future perspectives for energy production from solid biomass in the European industry. Renew. Sustain. Energy Rev. 112, 960-977. https://doi.org/10.1016/j.rser.2019.06.022

Marcelino, R.B.P., Andrade, L.N., Starling, M.C.V.M., Amorim, C.C., Barbosa, M.L.T., Lopes, R.P., Reis, B.G., Leão, M.M.D., 2016. Evaluation of aerobic and anaerobic biodegradability and toxicity assessment of real pharmaceutical wastewater from industrial production of antibiotics. Brazilian J. Chem. Eng. 33, 445-452. https://doi.org/10.1590/0104-6632.20160333s20150136

Mottet, A., Steyer, J.P., Déléris, S., Vedrenne, F., Chauzy, J., Carrère, H., 2009. Kinetics of thermophilic batch anaerobic digestion of thermal hydrolysed waste activated sludge. Biochem. Eng. J. 46, 169-175. https://doi.org/10.1016/j.bej.2009.05.003

Park, J.K., Tameda, K., Higuchi, S., Lee, N.H., 2017. Estimation of the methane generation rate constant using a large-scale respirometer at a landfill site. Environ. Eng. Res. 22, 339-346. https://doi.org/10.4491/eer.2017.001

Parnaudeau, V., Dignac, M.F., 2007. The organic matter composition of various wastewater sludges and their neutral detergent fractions as revealed by pyrolysis-GC/MS. J. Anal. Appl. Pyrolysis 78, 140-152. https://doi.org/10.1016/j.jaap.2006.06.002

Ponsá, S., Gea, T., Alerm, L., Cerezo, J., Sánchez, A., 2008. Comparison of aerobic and anaerobic stability indices through a MSW biological treatment process. Waste Manag. 28, 2735-2742. https://doi.org/10.1016/j.wasman.2007.12.002

Rath, J., Heuwinkel, H., Herrmann, A., 2013. Specific Biogas Yield of Maize Can Be Predicted by the Interaction of Four Biochemical Constituents. Bioenergy Res. 6, 939-952. https://doi.org/10.1007/s12155-013-9318-3

Roig, B., Thomas, O., 2003. Rapid estimation of global sugars by UV photodegradation and UV spectrophotometry. Anal. Chim. Acta 477, 325-329. https://doi.org/10.1016/S00032670(02)01427-7

Shao, L., Wang, T., Li, T., Lü, F., He, P., 2013. Comparison of sludge digestion under aerobic and anaerobic conditions with a focus on the degradation of proteins at mesophilic $\begin{array}{llll}\text { temperature. } & \text { Bioresour. } & \text { Technol. } & 131-137 .\end{array}$ https://doi.org/10.1016/j.biortech.2013.04.081

Sherwood, J., 2020. The significance of biomass in a circular economy. Bioresour. Technol. 300. https://doi.org/10.1016/j.biortech.2020.122755

Taylor, P., Soto, M., Veiga, M.C., Méndez, R., Lema, J.M., 1989. Semi - micro C . O . D . determination method for high - salinity wastewater SEMI-MICRO C . O . D . 


\section{DETERMINATION METHOD FOR HIGH-SALINITY WASTEWATER. Environ.} Technol. Lett. 37-41. https://doi.org/10.1080/09593338909384770

Thomsen, S.T., Spliid, H., Østergård, H., 2014. Statistical prediction of biomethane potentials based on the composition of lignocellulosic biomass. Bioresour. Technol. 154, 80-86. https://doi.org/10.1016/j.biortech.2013.12.029

Triolo, J.M., Sommer, S.G., Møller, H.B., Weisbjerg, M.R., Jiang, X.Y., 2011. A new algorithm to characterize biodegradability of biomass during anaerobic digestion: Influence of lignin concentration on methane production potential. Bioresour. Technol. 102, 9395-9402. https://doi.org/10.1016/j.biortech.2011.07.026

Tsapekos, P., Kougias, P.G., Angelidaki, I., 2015. Biogas production from ensiled meadow grass; effect of mechanical pretreatments and rapid determination of substrate biodegradability via physicochemical methods. Bioresour. Technol. 182, 329-335. https://doi.org/10.1016/j.biortech.2015.02.025

Wagland, S.T., Tyrrel, S.F., 2010. Test methods to aid in the evaluation of the diversion of biodegradable municipal waste (BMW) from landfill. Waste Manag. 30, 934-935. https://doi.org/10.1016/j.wasman.2010.01.016

Ward, A.J., 2016. Near-Infrared Spectroscopy for Determination of the Biochemical Methane Potential: State of the Art. Chem. Eng. Technol. 39, 611-619. https://doi.org/10.1002/ceat.201500315

Youcai, Z., 2018. Leachate Generation and Characteristics. Pollut. Control Technol. Leachate from Munic. Solid Waste 1-30. https://doi.org/10.1016/b978-0-12-815813-5.00001-2

Zerdazi, R., Boutraa, M., Melizi, A., Bencheikh Lehocine, M., Meniai, A.H., 2012. Application of respirometry in the assessment of chromium contaminated waste waters treatment. Energy Procedia 18, 438-448. https://doi.org/10.1016/j.egypro.2012.05.055

Zhang, Q., Vlaeminck, S.E., DeBarbadillo, C., Su, C., Al-Omari, A., Wett, B., Pümpel, T., Shaw, A., Chandran, K., Murthy, S., De Clippeleir, H., 2018. Supernatant organics from anaerobic digestion after thermal hydrolysis cause direct and/or diffusional activity loss for nitritation and anammox. Water Res. 143, 270-281. https://doi.org/10.1016/j.watres.2018.06.037 


\section{Assessment of a fast method to predict the biochemical methane potential based on biodegradable COD obtained by fractionation.}

Argiz L. ${ }^{\text {* }}$, Reyes C. , Belmonte M. , Franchi O. ${ }^{\text {, }}$, Campo R. ${ }^{\text {, }}$, Fra-Vázquez A. a , Val del Río A.

${ }^{\mathrm{a}}$, Mosquera-Corral A. ${ }^{\mathrm{a}}$, Campos J.L. ${ }^{\mathrm{c}}$

${ }^{a}$ CRETUS Institute, Department of Chemical Engineering, Universidade de Santiago de Compostela, 15782 Santiago de Compostela, Galicia, Spain

b Laboratorio de Biotecnología, Medio Ambiente e Ingeniería (LABMAI), Facultad de Ingeniería, Universidad de Playa Ancha, Avda. Leopoldo Carvallo 270, 2340000 Valparaíso, Chile.

${ }^{c}$ Facultad de Ingeniería y Ciencias, Universidad Adolfo Ibáñez, Avda. Padre Hurtado 750, Viña del Mar, Chile.

${ }^{\mathrm{d}}$ Dipartimento di Ingegneria Civile e Ambientale (DICEA), Università degli Studi Firenze, Via di Santa Marta, 3, 50139 Firenze, Italy.

* Corresponding author. Tel.: +34 881816784. E-mail address: $\underline{\text { luciaargiz.montes@ usc.es }}$ 


\section{TABLE CAPTIONS}

Table S1. Experimental conditions established for the realization of the BMP tests.

Table S2. Sample volumes required in fractionation assays depending on the COD of the substrate.

Table S3. Experimental conditions established for COD fractionation assays.

Table S4. Substrates characterization (part 2).

Table S5. COD fractionation results.

Table S6. Linear regression models for rapid BMP prediction from the different COD fractions.

Table S7. Results of the BMP and COD fractionation assays of the substrates considered for the interlaboratory comparison SC1-SC4. 


\section{Table S1}

\begin{tabular}{|c|c|c|c|c|c|c|c|}
\hline \multirow{2}{*}{ Parameter } & \multicolumn{7}{|c|}{ Substrate } \\
\hline & $\mathrm{S} 1$ & $\mathrm{~S} 2$ & S3 & S4 & S5 & S6 & S7 \\
\hline Temperature $\left({ }^{\circ} \mathrm{C}\right)$ & 37 & 37 & 37 & 37 & 37 & 37 & 37 \\
\hline Shaking speed (rpm) & 120 & 120 & 120 & 120 & 120 & 120 & 120 \\
\hline $\mathrm{pH}$ & $7.5-8.0$ & $7.5-8.0$ & $7.5-7.7$ & $7.5-8.0$ & $7.3-7.5$ & $7.5-8.0$ & $7.5-8.0$ \\
\hline Assays duration (d) & 30 & 45 & 20 & 140 & 15 & 55 & 45 \\
\hline ISR (VS basis) & 1.5 & 1.5 & 2.0 & 1.25 & 2.0 & 3.0 & 2.5 \\
\hline \multicolumn{8}{|l|}{ Inoculum } \\
\hline Origin & $\begin{array}{l}\text { Lab-scale anaerobic } \\
\text { reactor }\end{array}$ & $\begin{array}{l}\text { Lab-scale anaerobic } \\
\text { reactor }\end{array}$ & $\begin{array}{l}\text { Lab-scale anaerobic } \\
\text { reactor }\end{array}$ & $\begin{array}{l}\text { Lab-scale anaerobic } \\
\text { reactor }\end{array}$ & $\begin{array}{l}\text { Industrial anaerobic } \\
\text { reactor adapted to } \\
\text { high salinity }\end{array}$ & $\begin{array}{l}\text { Industrial anaerobic } \\
\text { reactor adapted to } \\
\text { high salinity }\end{array}$ & $\begin{array}{c}\text { Lab-scale } \\
\text { anaerobic reactor }\end{array}$ \\
\hline Degassing time (d) & 3 & 3 & 2 & 4 & 3 & 3 & 3 \\
\hline $\mathrm{V}(\mathrm{mL})$ & 16.95 & 78.27 & 85.00 & 125.00 & 130.00 & 242.76 & 275.00 \\
\hline VS (g/L) & 0.20 & 1.05 & 2.47 & 2.62 & 4.10 & 2.87 & 6.47 \\
\hline \multicolumn{8}{|l|}{ Substrate } \\
\hline Conditioning & - & - & - & $\begin{array}{c}90 \% \text { of } \mathrm{NH}_{4}^{+} \\
\text {stripping and } 5 \% \text { of } \\
\text { COD }_{t} \text { removal }\end{array}$ & - & - & - \\
\hline $\mathrm{V}(\mathrm{mL})$ & 265.00 & 178.00 & 274.36 & 245.77 & 208.20 & 88.57 & 82.37 \\
\hline VSS (g/L) & 0.06 & 0.06 & 0.02 & 0.04 & 0.30 & 0.24 & - \\
\hline $\mathrm{VS}(\mathrm{g} / \mathrm{L})$ & - & - & - & - & - & - & 3.24 \\
\hline Initial COD added $(\mathrm{g} / \mathrm{L})$ & 0.50 & 1.53 & 1.81 & 3.53 & 1.86 & 1.54 & 4.05 \\
\hline
\end{tabular}

ISR (inoculum to substrate ratio), V (volume), VS (volatile solids), VSS (volatile suspended solids), COD (chemical oxygen demand) 
Table S2

\begin{tabular}{ccc}
\hline Substrate $\mathbf{C O D}_{\mathbf{t}}(\mathbf{m g} / \mathbf{L})$ & \multicolumn{2}{c}{ Sample volume $(\mathbf{m L})$} \\
$\mathrm{COD}_{\mathbf{b}}$ & $\mathrm{S}_{\mathrm{b}}$ \\
\hline$<300$ & $80-50$ & 50 \\
$300-5000$ & $40-20$ & $40-20$ \\
$5000-10000$ & $20-15$ & $20-15$ \\
$10000-25000$ & $15-10$ & $15-10$ \\
$>25000$ & $10-5$ & $10-5$ \\
\hline
\end{tabular}




\section{Table S3}

\begin{tabular}{|c|c|c|c|c|c|c|c|c|}
\hline \multirow{2}{*}{\multicolumn{2}{|c|}{ Parameter }} & \multicolumn{7}{|c|}{ Substrate } \\
\hline & & $\mathrm{S} 1$ & $\mathrm{~S} 2$ & $\mathrm{~S} 3$ & S4 & S5 & S6 & S7 \\
\hline Temperature $\left({ }^{\circ} \mathrm{C}\right)$ & & 25 & 25 & 25 & 25 & 25 & 25 & 25 \\
\hline ATU (mg/mg VSS) & & 2.50 & 3.00 & 3.00 & 3.00 & 2.00 & 2.50 & 3.00 \\
\hline Duration (h) & $\begin{array}{l}\mathrm{COD}_{\mathrm{b}} \\
\mathrm{S}_{\mathrm{b}}\end{array}$ & $\begin{array}{l}1.5-2.5 \\
1.5-2.0\end{array}$ & $\begin{array}{c}1.5-2.8 \\
1.5-2\end{array}$ & $\begin{array}{l}1.5-2 \\
1.5-2\end{array}$ & $\begin{array}{c}6-6.2 \\
5.3-6.5\end{array}$ & $\begin{array}{l}6-7 \\
2-3\end{array}$ & $\begin{array}{l}1.5 \\
1.5\end{array}$ & $\begin{array}{c}20-35 \\
2-3\end{array}$ \\
\hline \multicolumn{9}{|l|}{ Sludge } \\
\hline Origin & & $\begin{array}{l}\text { Pilot-scale } \\
\text { MBR treating } \\
\text { S1 }\end{array}$ & WWTP AS reactor & $\begin{array}{l}\text { WWTP AS } \\
\text { reactor }\end{array}$ & $\begin{array}{l}\text { WWTP AS } \\
\text { reactor }\end{array}$ & $\begin{array}{l}\text { Pilot-scale GSBR } \\
\text { treating S5 }\end{array}$ & $\begin{array}{l}\text { Lab-scale aerobic } \\
\text { SBR treating S6 }\end{array}$ & $\begin{array}{l}\text { WWTP AS } \\
\text { reactor }\end{array}$ \\
\hline Conditioning & & 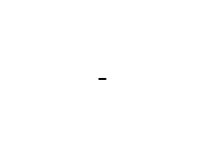 & - & - & - & $\begin{array}{l}\text { Sludge washed with } \\
\text { distilled water } \\
\text { mimicking sludge } \\
\mathrm{NaCl} \text { concentration }\end{array}$ & - & \\
\hline Dilution & & - & $1: 2$ & $1: 2$ & $1: 2$ & - & - & $1: 2$ \\
\hline VSS (g/L) & & 2.23 & 3.43 & 3.12 & 3.20 & $1.05 * *$ & 1.00 & 3.00 \\
\hline \multicolumn{9}{|l|}{ Substrate } \\
\hline Conditioning for $\mathrm{S}_{\mathrm{s}}$ determi & ation & $\begin{array}{l}\text { Centrifugation } \\
+ \text { filtering }\end{array}$ & $\begin{array}{c}\text { Coagulation }+ \\
\text { Settling }+ \text { filtering } \\
*\end{array}$ & $\begin{array}{l}\text { Centrifugation } \\
+ \text { filtering }\end{array}$ & $\begin{array}{l}\text { Centrifugation } \\
+ \text { filtering }\end{array}$ & $\begin{array}{l}\text { Centrifugation + } \\
\text { filtering }\end{array}$ & $\begin{array}{l}\text { Centrifugation + } \\
\text { filtering }\end{array}$ & $\begin{array}{l}\text { Centrifugation } \\
+ \text { filtering }\end{array}$ \\
\hline \multirow{2}{*}{$\mathrm{V}(\mathrm{mL})$} & $\mathrm{COD}_{\mathrm{b}}$ & 20 & 20 & 20 & 20 & 20 & 10 & 10 \\
\hline & $\mathrm{S}_{\mathrm{b}}$ & 40 & 20 & 20 & 20 & 20 & 10 & 20 \\
\hline Initial COD added (mg/L) & $\begin{array}{l}\mathrm{COD}_{\mathrm{b}} \\
\mathrm{S}_{\mathrm{b}}\end{array}$ & $\begin{array}{l}13.86 \\
14.93\end{array}$ & $\begin{array}{l}63.02 \\
49.71\end{array}$ & $\begin{array}{l}48.57 \\
47.68\end{array}$ & $\begin{array}{l}110.76 \\
100.67\end{array}$ & $\begin{array}{c}65.61 \\
7.38\end{array}$ & $\begin{array}{l}173.60 \\
165.41\end{array}$ & $\begin{array}{l}90.04 \\
33.31\end{array}$ \\
\hline
\end{tabular}

AS (activated sludge), GSBR (granular biomass system), MBR (membrane bioreactor), SBR (sequencing batch reactor).

* Addition of $100 \mathrm{mg} / \mathrm{L}$ of $\mathrm{Al}_{2}\left(\mathrm{SO}_{4}\right)_{3} ; 2 \mathrm{~h} 30 \mathrm{~min}$ of severe stirring, $20 \mathrm{~min}$ of gentle stirring and $20 \mathrm{~min}$ of settling.

** Lower VSS (if compared with manufacturer recommendations) since it was granular biomass with very high heterotrophic activity. 


\section{Table S4}

\begin{tabular}{|c|c|c|c|c|c|c|c|c|c|c|c|}
\hline \multirow{2}{*}{ Parameter } & \multicolumn{7}{|c|}{ Sample } & \multirow[b]{2}{*}{ SC1 } & \multirow[b]{2}{*}{$\mathrm{SC2}$} & \multirow[b]{2}{*}{ SC3 } & \multirow[b]{2}{*}{$\mathrm{SC} 4$} \\
\hline & S1 & S2 & S3 & S4 & S5 & S6 & S7 & & & & \\
\hline $\mathrm{VS}-\mathrm{VSS} / \mathrm{TSS}-\mathrm{TS}(\%)$ & 90.8 & 96.4 & 62.4 & 55.3 & 69.4 & 64.6 & 83.6 & 64.2 & 91.7 & 96.8 & 87.3 \\
\hline $\mathrm{TOC}(\mathrm{mg} / \mathrm{L})$ & 130 & 1,108 & 971 & 2,535 & 60 & 7,880 & 712 & 850 & 1,710 & 120 & 850 \\
\hline $\mathrm{IC}(\mathrm{mg} / \mathrm{L})$ & 285 & 6 & 1,039 & 3,357 & 21 & 24 & 15 & 149 & 552 & 104 & 75 \\
\hline $\mathrm{C} / \mathrm{N}$ & 8.6 & 59.7 & 0.7 & 0.6 & 2.6 & 7.3 & 8.3 & 98.8 & 2.8 & 1.4 & 1.2 \\
\hline
\end{tabular}




\section{Table S5}

\begin{tabular}{|c|c|c|c|c|c|c|c|c|}
\hline \multirow{2}{*}{\multicolumn{2}{|c|}{ Parameter }} & \multicolumn{7}{|c|}{ Substrate } \\
\hline & & $\mathrm{S} 1$ & $\mathrm{~S} 2$ & S3 & $\mathrm{S} 4$ & S5 & S6* & S7 \\
\hline \multicolumn{9}{|c|}{ Experimental data } \\
\hline \multirow{2}{*}{$\mathrm{COD}_{\mathrm{b}}$} & $\mathrm{g} /$ & $0.45 \pm 0.01$ & $2.56 \pm 0.05$ & $0.48 \pm 0.02$ & $2.71 \pm 0.21$ & $1.33 \pm 0.10$ & 13.15 & $11.68 \pm 0.53$ \\
\hline & $\%$ & $63.77 \pm 1.61$ & $79.68 \pm 1.63$ & $19.42 \pm 0.62$ & $47.90 \pm 3.65$ & $39.72 \pm 3.10$ & 75.75 & $63.31 \pm 2.87$ \\
\hline \multirow{2}{*}{$\mathrm{S}_{\mathrm{b}}$} & & $0.37 \pm 0.01$ & $2.16 \pm 2.93$ & $0.45 \pm 0.02$ & $2.23 \pm 0.07$ & $0.27 \pm 0.02$ & 12.57 & $2.19 \pm 0.05$ \\
\hline & $\%$ & $51.89 \pm 1.26$ & $67.29 \pm 3.41$ & $17.99 \pm 0.69$ & $39.53 \pm 1.31$ & $8.20 \pm 0.54$ & $72.43 *$ & $11.89 \pm 0.25$ \\
\hline \multicolumn{9}{|l|}{ Calculations } \\
\hline \multirow{2}{*}{$\mathrm{X}_{\mathrm{b}}$} & & 0.08 & 0.40 & 0.04 & 0.47 & 1.05 & 0.58 & 9.49 \\
\hline & $\%$ & 11.88 & 12.39 & 1.42 & 8.38 & 31.51 & 3.32 & 51.42 \\
\hline \multirow{2}{*}{$\mathrm{COD}_{\mathrm{i}}$} & g/ & 0.26 & 0.65 & 2.00 & 2.94 & 2.02 & 4.21 & 6.77 \\
\hline & $\%$ & 36.23 & 20.32 & 15.27 & 52.10 & 60.28 & 24.25 & 36.69 \\
\hline \multirow{2}{*}{$\mathrm{S}_{\mathrm{i}}$} & $\mathrm{L}^{\mathrm{g} /}$ & 0.02 & 0.44 & 1.99 & 2.90 & 0.09 & 4.13 & 0.12 \\
\hline & $\%$ & 3.04 & 13.55 & 80.18 & 51.37 & 2.83 & 23.81 & 0.63 \\
\hline \multirow{2}{*}{$\mathrm{X}_{\mathrm{i}}$} & & 0.23 & 0.22 & 0.01 & 0.04 & 1.92 & 0.08 & 6.65 \\
\hline & $\%$ & 33.19 & 6.67 & 0.41 & 0.73 & 57.45 & 0.44 & 36.05 \\
\hline
\end{tabular}

* No triplicate data available. 
Table S6

\begin{tabular}{ccccc}
\hline Model & Coefficients & Equation & $\mathbf{R}^{2 *}$ & SE $^{* *}$ \\
\hline M1 & $\mathrm{COD}_{\mathrm{b}}$ & $1.094 \cdot \mathrm{COD}_{\mathrm{b}}$ & 0.998 & 317.496 \\
M2 & $\mathrm{COD}_{\mathrm{i}}$ & $1.910 \cdot \mathrm{COD}_{\mathrm{i}}$ & 0.628 & 4916.954 \\
M3 & $\mathrm{S}_{\mathrm{b}}$ & $1.308 \cdot \mathrm{S}_{\mathrm{b}}$ & 0.759 & 3960.217 \\
M4 & $\mathrm{X}_{\mathrm{b}}$ & $1.412 \cdot \mathrm{X}_{\mathrm{b}}$ & 0.470 & 5867.588 \\
M5 & $\mathrm{S}_{\mathrm{i}}$ & $2.480 \cdot \mathrm{S}_{\mathrm{i}}$ & 0.468 & 5879.613 \\
M6 & $\mathrm{X}_{\mathrm{i}}$ & $1.412 \cdot \mathrm{X}_{\mathrm{i}}$ & 0.404 & 6222.113 \\
M7 & $\mathrm{COD}_{\mathrm{b}}, \mathrm{COD}_{\mathrm{i}}$ & $1.126 \cdot \mathrm{COD}-0.088 \cdot \mathrm{COD}_{\mathrm{i}}$ & 0.999 & 290.844 \\
M8 & $\mathrm{S}_{\mathrm{b}}, \mathrm{X}_{\mathrm{b}}$ & $1.125 \cdot \mathrm{S}_{\mathrm{b}}-1.041 \cdot \mathrm{X}_{\mathrm{b}}$ & 0.999 & 236.679 \\
M9 & $\mathrm{S}_{\mathrm{i}}, \mathrm{X}_{\mathrm{i}}$ & $2.392 \cdot \mathrm{S}_{\mathrm{i}}+1.735 \cdot \mathrm{X}_{\mathrm{i}}$ & 0.839 & 3547.090 \\
M10 & $\mathrm{S}_{\mathrm{b}}, \mathrm{X}_{\mathrm{b}}, \mathrm{COD}_{\mathrm{i}}$ & $1.125 \cdot \mathrm{S}_{\mathrm{b}}+1.041 \cdot \mathrm{X}_{\mathrm{b}}-0.01 \cdot \mathrm{COD}_{\mathrm{i}}$ & 0.999 & 264.614 \\
M11 & $\mathrm{COD}_{\mathrm{b}}, \mathrm{S}_{\mathrm{i}}, \mathrm{X}_{\mathrm{i}}$ & $1.113 \cdot \mathrm{COD}_{\mathrm{b}}+0.018 \cdot \mathrm{S}_{\mathrm{i}}-0.089 \cdot \mathrm{X}_{\mathrm{i}}$ & 0.999 & 288.373 \\
M12 & $\mathrm{S}_{\mathrm{b}}, \mathrm{X}_{\mathrm{b}}, \mathrm{S}_{\mathrm{i}}, \mathrm{X}_{\mathrm{i}}$ & $1.126 \cdot \mathrm{S}_{\mathrm{b}}+0.950 \cdot \mathrm{X}_{\mathrm{b}}+0.007 \cdot \mathrm{S}_{\mathrm{i}}+0.126 \cdot \mathrm{X}_{\mathrm{i}}$ & 0.999 & 292.637 \\
\hline
\end{tabular}

* Correlation coefficient. Regression through the origin (model without intersection). $\mathrm{R}^{2}$ measures the proportion of the variability in the dependent variable on the origin explained by the regression.

** Standard Error of the estimation. 


\section{Table S7}

\begin{tabular}{|c|c|c|c|c|}
\hline & \multicolumn{4}{|c|}{ Sample } \\
\hline & SC1 & $\mathrm{SC} 2$ & SC3 & $\mathrm{SC} 4$ \\
\hline \multicolumn{5}{|l|}{ BMP tests } \\
\hline Sludge origin & $\begin{array}{l}\text { Full-scale } \\
\text { anaerobic reactor } \\
\text { treating pig slurry }\end{array}$ & $\begin{array}{c}\text { Full-scale } \\
\text { anaerobic sludge } \\
\text { digester }\end{array}$ & $\begin{array}{c}\text { Full-scale UASB } \\
\text { reactor treating } \\
\text { tobacco } \\
\text { wastewater }\end{array}$ & $\begin{array}{c}\text { Full-scale } \\
\text { anaerobic } \\
\text { reactor treating } \\
\text { pig slurry }\end{array}$ \\
\hline $\mathrm{COD}_{\text {met }}(\%)$ & $63.22 \pm 1.99$ & $24.62 \pm 2.84$ & $21.85 \pm 3.44$ & $85.68 \pm 2.88$ \\
\hline \multicolumn{5}{|c|}{ COD fractionation } \\
\hline Sludge origin & $\begin{array}{l}\text { WWTP AS } \\
\text { reactor }\end{array}$ & $\begin{array}{l}\text { WWTP AS } \\
\text { reactor }\end{array}$ & $\begin{array}{l}\text { WWTP AS } \\
\text { reactor }\end{array}$ & $\begin{array}{l}\text { WWTP AS } \\
\text { reactor }\end{array}$ \\
\hline $\mathrm{COD}_{\mathrm{b}}(\%)$ & $66.08 \pm 1.70$ & $17.86 \pm 2.63$ & $19.41 \pm 3.93$ & $84.30 \pm 2.86$ \\
\hline
\end{tabular}




\section{FIGURE CAPTIONS}

Figure S1. COD fractions scheme.

Figure S2. Exemplification of $\mathrm{COD}_{\text {met }}$ and $\mathrm{COD}_{\mathrm{b}}$ evolution over time. Triplicate data of substrate A) S2 (higher \% $\mathrm{COD}_{\mathrm{b}}$ ). and B) S3 (lower \% $\mathrm{COD}_{\mathrm{b}}$ ). 


\section{Figure S1}

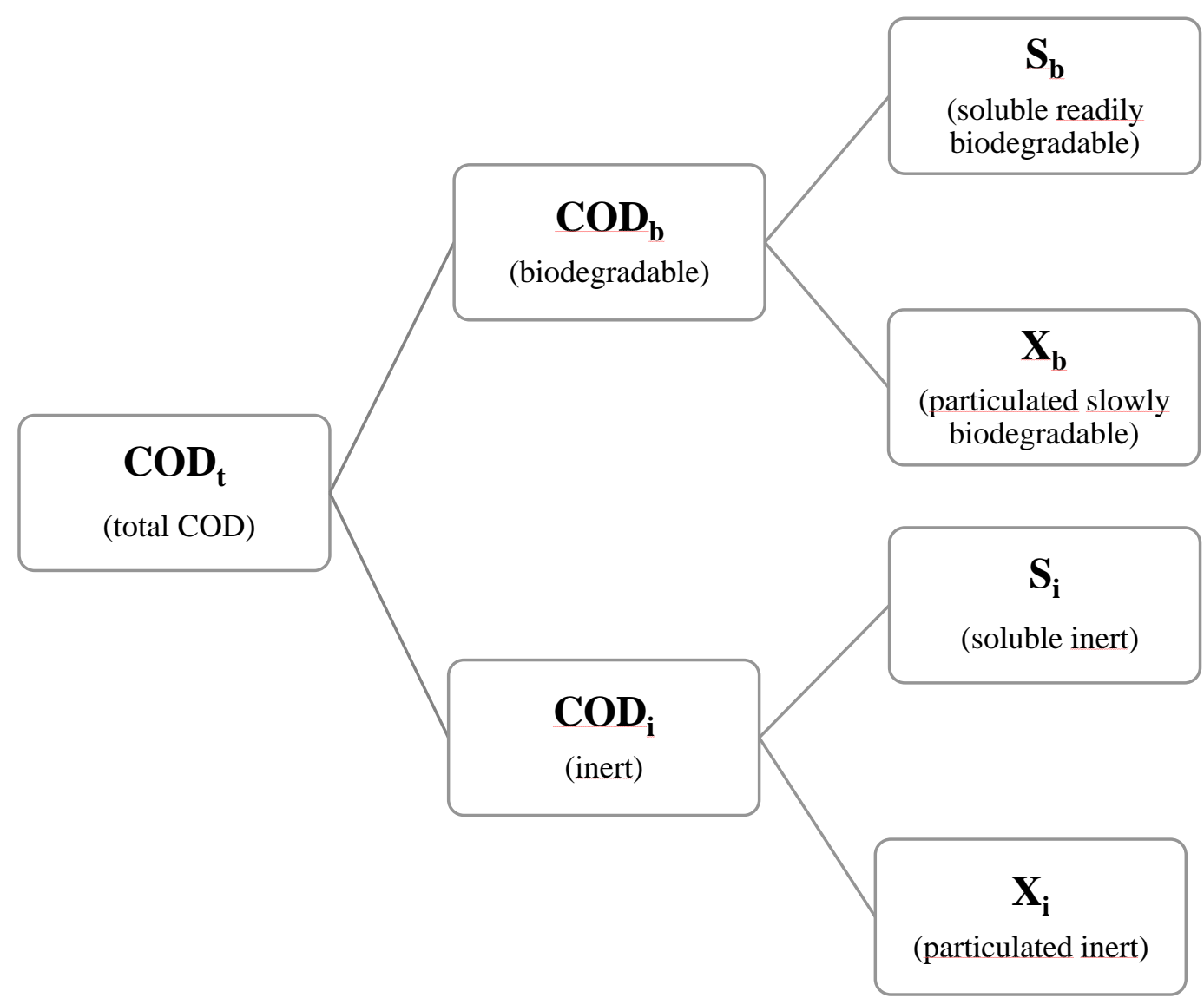




\section{Figure S2}

A)
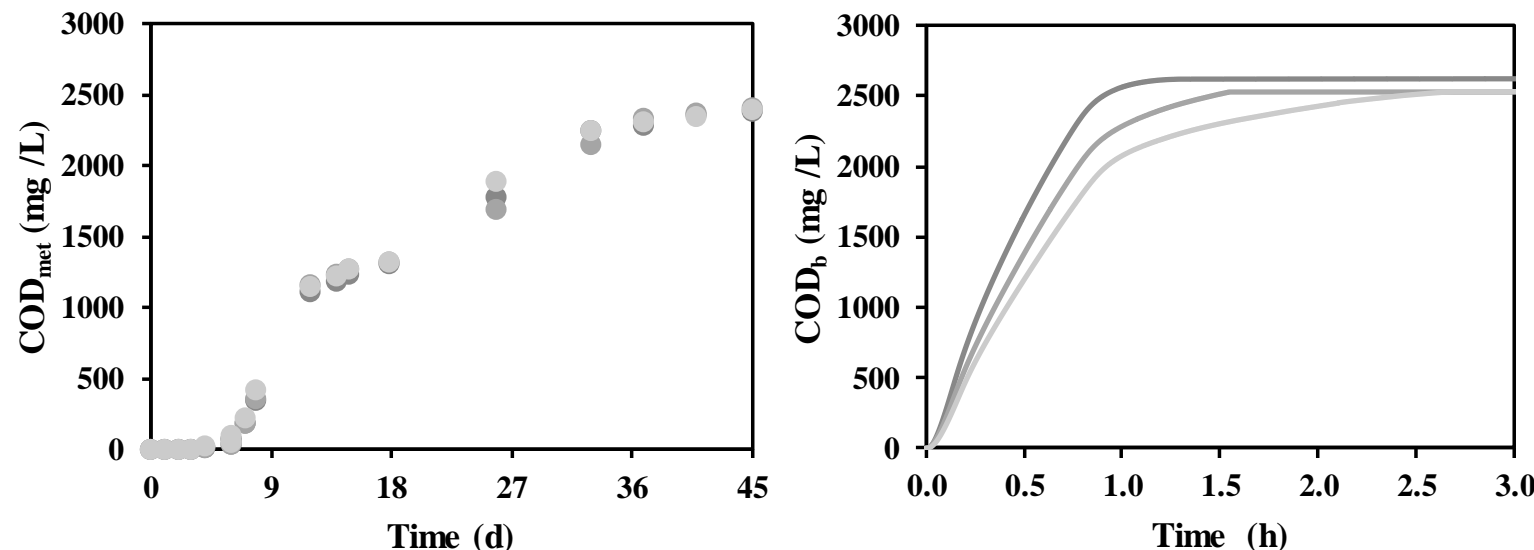

B)
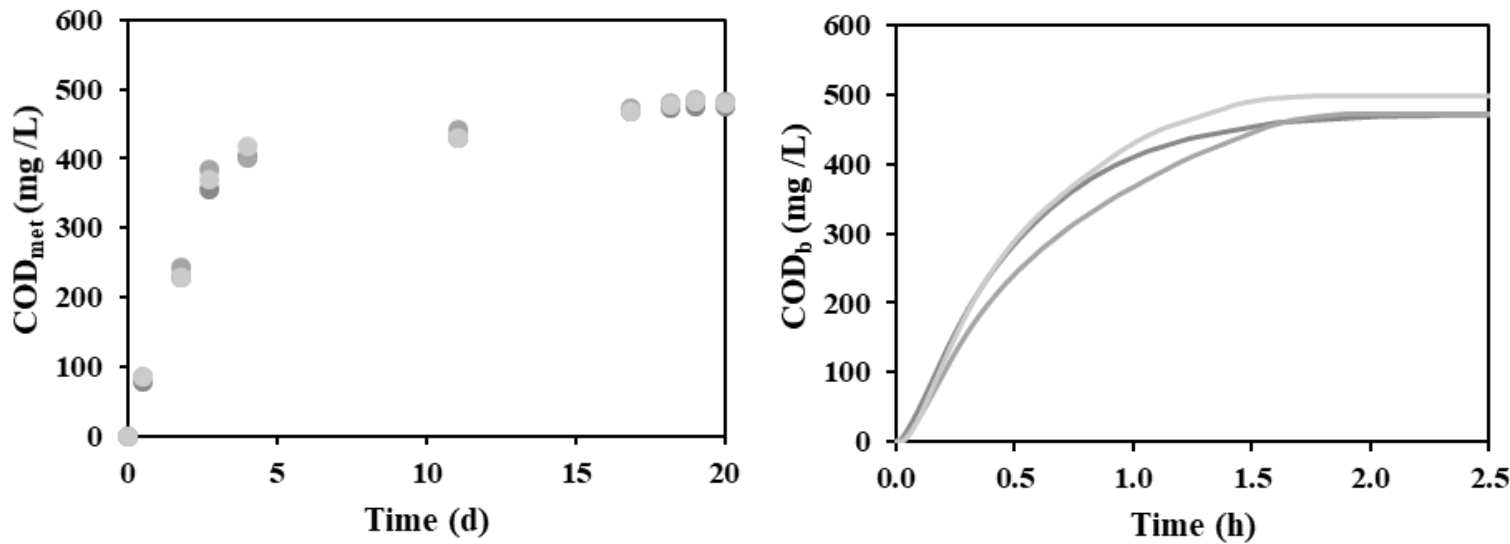


\section{Credit Author Statement}

Lucía Argiz: investigation, writing-original draft, formal analysis, visualization; Claudia Reyes: investigation; validation; Marisol Belmonte: supervision, project administration, funding acquisition; Óscar Franchi: validation; Riccardo Campo: methodology, validation; Andrea Fra-Vázquez: methodology, validation; Ángeles Val del Río: formal analysis, validation, visualization, supervision, funding acquisition; Anuska Mosquera: validation, supervision, project administration, funding acquisition; José Luis Campos: methodology, validation, supervision, project administration, funding acquisition. 